\title{
Treaties, Human Rights, and Conditional Consent
}

\section{Citation}

Curtis A. Bradley \& Jack L. Goldsmith, Treaties, Human Rights, and Conditional Consent, 149 U. Pa. L. Rev. 399 (2000).

\section{Published Version}

http://scholarship.law.upenn.edu/penn_law_review/vol149/iss2/1/

\section{Permanent link}

http://nrs.harvard.edu/urn-3:HUL.InstRepos:12956321

\section{Terms of Use}

This article was downloaded from Harvard University's DASH repository, and is made available under the terms and conditions applicable to Other Posted Material, as set forth at http:// nrs.harvard.edu/urn-3:HUL.InstRepos:dash.current.terms-of-use\#LAA

\section{Share Your Story}

The Harvard community has made this article openly available.

Please share how this access benefits you. Submit a story.

\section{Accessibility}




\section{University of Pennsylvania \\ Law Review}

FOUNDED 1852

Formerly

American Law Register

No. 2

\section{ARTICLES}

TREATIES, HUMAN RIGHTS, AND CONDITIONAL CONSENT

CURTIS A. BRADLEY ${ }^{\dagger} \&$ JACK L. GOLDSMITH ${ }^{\dagger}$

\section{INTRODUCTION}

Article II of the Constitution grants the President the "Power, by and with the Advice and Consent of the Senate, to make Treaties, provided two thirds of the Senators present concur." When the President obtains the Senate's advice and consent and ratifies a treaty, the treaty binds the United States internationally. If the treaty is "selfexecuting," it also becomes part of domestic federal law, superseding

$\dagger$ Professor, University of Virginia School of Law.

t† Professor, University of Chicago Law School.

For their helpful comments and suggestions, we thank David Bederman, Kathryn Bradley, David Fidler, Ryan Goodman, John Manning, David Martin, Bernard Meltzer, Madeline Morris, John Nagle, Caleb Nelson, Art Rynearson, John Setear, David Sloss, Peter Spiro, Paul Stephan, David Strauss, Carlos Vázquez, Adrian Vermeule, Phil Weiser, and participants in workshops held at the University of Chicago, University of Notre Dame, University of Texas, and University of Virginia law schools.

U.S. ConsT. art. II, \$2, cl. 2.

${ }^{2}$ By "self-executing," we mean enforceable in U.S. courts without implementing 
both prior inconsistent federal law (treaties and statutes) and prior inconsistent state law. ${ }^{3}$

The constitutional treatymaking process was designed with a particular type of treaty in mind. In the late eighteenth century, treaties were primarily bilateral agreements that focused on relations between nations, regarding such issues as trade and peace. Nations entered into reciprocal relationships with other nations to achieve mutual gain. By contrast, many modern treaties do not regulate relations between nations and do not confer specific reciprocal benefits on the parties. Instead, they are multilateral instruments, open for ratification by all nations and designed to regulate the intra-national relations between nations and their citizens. This distinction is most pronounced with respect to human rights treaties.

Modern human rights treaties present several challenges for the U.S. constitutional system. The first challenge concerns substance. Human rights treaty provisions are sometimes in tension with either constitutionally guaranteed rights (like the First Amendment) or well settled and democratically popular practices (such as capital punishment for heinous crimes). The second challenge concerns scope. Human rights treaties touch on almost every aspect of domestic civil, political, and cultural life. In addition, the language of these treaties is often vague and open-ended. If such treaties had the status of selfexecuting federal law, they would generate significant litigation and uncertainty regarding the application and validity of numerous domestic laws. The third challenge concerns structure. Constitutional principles relating to separation of powers suggest that domestic federal law with respect to human rights should be made through a lawmaking process that involves the House of Representatives. Similarly, constitutional principles relating to federalism suggest that some matters should be regulated by state, rather than federal, officials.

For many years, these challenges led U.S. treatymakers to decline to ratify any of the major post-World War II human rights treaties. Beginning in the 1970 s, the treatymakers crafted a way to commit the

legislation. See, e.g., Foster v. Neilson, 27 U.S. (2 Pet.) 253, 314 (1829) (distinguishing between self-executing and non-self-executing treaties).

${ }^{3}$ The Supremacy Clause of the Constitution provides that treaties "shall be the supreme Law of the Land" and that the "Judges in every State shall be bound thereby." U.S. CONST. art. VI, cl. 2. The Supreme Court has long held that treaties supersede inconsistent state law. See, e.g., Ware v. Hylton, 3 U.S. (3 Dall.) 199, 236-37 (1796). It also has held that when there is a conflict between a treaty and a federal statute, the later in time prevails as a matter of U.S. law. See, e.g., Whitney v. Robertson, 124 U.S. 190,194 (1888). 
United States to human rights treaties in the international arena while accommodating domestic concerns. They achieved these dual aims by ratifying the treaties with a set of conditions. These conditions take the form of reservations, understandings, and declarations-collectively, "RUDs"-to U.S. ratification. The RUDs address each of the challenges outlined above. With regard to the problem of substance, U.S. treatymakers decline to commit the United States to certain substantive provisions in the treaties. With regard to the problems of scope and structure, the treatymakers declare that the treaties are not self-executing and thus not enforceable in U.S. courts until implemented by congressional legislation. Treatymakers also express an understanding that some provisions of the treaties may be implemented by state and local governments rather than by the federal government.

Many international law commentators have argued that the RUDs are legally invalid, bad policy, or both. ${ }^{4}$ With respect to legal validity, commentators argue, among other things: that the reservations violate international law restrictions on treaty conditions; that the nonself-execution declarations are inconsistent with the Supremacy Clause of the Constitution; and that the federalism understandings are inconsistent with the national government's responsibility, under both domestic and international law, for treaty violations. As for the

See, e.g., M. Cherif Bassiouni, Reflections on the Ratification of the International Covenant on Civil and Political Rights by the United States, 42 DEPAUL L. REV. 1169, 1173 (1993); Lori Fisler Damrosch, The Role of the United States Senate Concerning "SelfExecuting" and "Non-Self-Executing" Treaties, 67 CHI.-KENT L. REV. 515, 532 (1991); Malvina Halberstam, United States Ratification of the Convention on the Elimination of All Forms of Discrimination Against Women, 31 GEO. WASH. J. INT'L L. \& ECON. 49, 50 (1997); Louis Henkin, U.S. Ratification of Human Rights Treaties: The Ghost of Senator Bricker, 89 AM. J. INT'L L. 341, 342-50 (1995); Ved P. Nanda, The United States Reservation to the Ban on the Death Penalty for Juvenile Offenders: An Appraisal Under the International Covenant on Civil and Political Rights, 42 DEPAUL L. REV. 1311, 1335 (1993); Jordan J. Paust, Avoiding "Fraudulent" Executive Policy: Analysis of Non-Self-Execution of the Covenant on Civil and Political Rights, 42 DEPAUL L. REv. 1257, 1283 (1993); John Quigley, The International Covenant an Civil and Political Rights and the Supremay Clause, 42 DEPAUL L. REv. 1287, 1302-103 (1993); Stefan A. Riesenfeld \& Frederick M. Abbott, The Scope of U.S. Senate Control Over the Conclusion and Operation of Treaties, 67 CHI.KENT L. REV. 571, 643 (1991); William A. Schabas, Invalid Reservations to the International Covenant on Civil and Political Rights: Is the United States Still a Party?, 21 BROOK. J. INT'L L. 277, 285 (1995); David Weissbrodt, United States Ratification of the Human Rights Covenants, 63 MINN. L. REv. 35, 77 (1978); Charles H. Dearborn, III, Note, The Domestic Legal Effect of Declarations That Treaty Provisions Are Not Self-Executing, 57 TEX. L. REV. 233, 238 (1979); Louis N. Schulze, Jr., Note, The United States' Detention of Refugees: Evidence of the Senate's Flawed Ratification of the International Covenant on Civil and Political Rights, 23 NEW ENG. J. ON CRIM. \& CN. CONFINEMENT 641 (1997). 
policy objections to RUDs, commentators have argued that they show disrespect for international law and, in the words of Professor Louis Henkin, "threaten [] to undermine a half-century of effort to establish international human rights standards as international law."

This Article challenges the conventional academic wisdom concerning both the legality and desirability of RUDs attached to human rights treaties. The RUDs, we argue, reflect a sensible accommodation of competing domestic and international considerations. Among other things, they help bridge the political divide between isolationists who want to preserve the United States's sovereign prerogatives, and internationalists who want the United States to increase its involvement in international institutions-a divide that has had a debilitating effect on U.S. participation in international human rights regimes since the late 1940s. Perhaps more importantly, the RUDs help reconcile fundamental changes in international law with the requirements of the U.S. constitutional system. The RUDs achieve these ends, we contend, in ways that are valid under both international and domestic law.

To date, courts have enforced the RUDs, but no court has considered their validity in any detail. ${ }^{6}$ The practical significance of the issue was illustrated recently in a Nevada death penalty case, Domingues $v$. State. ${ }^{7}$ In that case, the State of Nevada sentenced Michael Domingues to death for two murders committed when he was sixteen years of age. ${ }^{8}$ The U.S. Supreme Court has held that the Eighth Amendment does not prohibit the execution of sixteen-year-old offenders. ${ }^{9}$ Domingues nevertheless challenged his death sentence in the Nevada courts on the ground that it was inconsistent with the International Covenant on Civil and Political Rights, a multilateral treaty ratified by the United States in 1992. ${ }^{10}$ This treaty contains a provision prohibiting the imposition of a death sentence for the commission of a crime

${ }^{5}$ Henkin, supra note 4 , at 349.

${ }^{6}$ See, e.g., Igartua de la Rosa v. United States, 32 F.3d 8, 10 n.1 (1st Cir. 1994); Sandhu v. Burke, No. 97 Civ. 4608 (JGK), 2000 U.S. Dist. LEXIS 3584, at *32 (S.D.N.Y. Feb. 10, 2000); Ralk v. Lincoln County, 81 F. Supp. 2d 1372, 1380 (S.D. Ga. 2000); Calderon v. Reno, 39 F. Supp. 2d 943, 956 (N.D. Ill. 1998); Jama v. INS, 22 F. Supp. 2d 353, 362 (D.N.J. 1998); White v. Paulsen, 997 F. Supp. 1380, 1387 (E.D. Wash. 1998); In re Cheung, 968 F. Supp. 791, 803 n.17 (D. Conn. 1997); Domingues v. State, 961 P.2d 1279, 1280 (Nev. 1998).

${ }^{7} 961$ P.2d at 1279 .

${ }^{8}$ Id.

${ }^{9}$ Stanford v. Kentucky, 492 U.S. 361, 380 (1989).

${ }^{10}$ International Covenant on Civil and Political Rights, Dec. 16, 1966, 999 U.N.T.S. 171, 6 I.L.M. 368 [hereinafter ICCPR]. 
by a person under the age of eighteen." When it ratified the treaty, however, the United States attached a reservation stating that it did not consent to this provision, as well as a declaration stating that the entire treaty was non-self-executing. Domingues contended that these conditions were invalid and should thus be disregarded by U.S. courts. Although a majority of the Nevada Supreme Court rejected this argument, ${ }^{12}$ two dissenting justices took Domingues's treaty argument seriously. ${ }^{1.8}$ Arguments similar to those made by Domingues were made recently in connection with executions scheduled in a number of other states. ${ }^{14}$

Our analysis proceeds as follows. Part I describes the historical background of the RUDs and their principal features. Part II shows that the international law objections to the RUDs are questionable on their own terms and that, in any event, the conclusion usually drawn from these objections-that the United States is bound by the human rights treaties as if it had never attached the RUDs-is inconsistent with international law principles relating to national consent. Part III demonstrates that, regardless of the legality of the RUDs under international law, they are valid under domestic constitutional law and thus must be enforced by U.S. courts. Finally, Part IV discusses a variety of functional benefits-including benefits for international human rights law-associated with the treatymakers' conditional consent power.

\section{HISTORY, PURPOSES, AND CONTENT OF RUDS}

This Part sets out the background needed to evaluate the validity of the RUDs. Part I.A provides a brief history of conditional consent in the United States, from the Founding until World War II. Part I.B

"Id., art. 6, para. 5, 999 U.N.T.S at 174 ("Sentence of death shall not be imposed for crimes committed by persons below eighteen years of age ....").

${ }^{12}$ Domingues, 961 P.2d at 1280.

${ }^{13}$ Id. at 1280-81 (Springer \& Rose, J]., dissenting). After requesting the views of the Solicitor General, Domingues v. Nevada, 526 U.S. 1156 (1999), the U.S. Supreme Court denied Domingues's petition for review. Domingues v. Nevada, 120 S. Ct. 396 (1999). The Solicitor General argued that the petition should be denied. Brief for the United States as Amicus Curiae, Domingues v. Nevada, 526 U.S. 1156 (1999) (No. 988327) [hereinafter Domingues Brief].

1* See, e.g., Ex Parte Pressley, No. 1981061, 2000 Ala. LEXIS 30, at*15-*16 (Jan. 28, 2000); McFarland v. State, 989 S.W.2d 899, 906 (Ark. 1999); Raymond Bonner, Georgia Execulion is Stayed in Case of Youthful Offender, N.Y. TIMES, Aug. 23, 2000, at A12; Frank Green, Two Juvenile Offenders Face Execution; Gilmore, High Court Asked to Spare Them, RICH. TIMES DISPATCH, Jan. 10, 2000, at B1; United Press International, Texas Inmate Executed for Teen Murder, Jan. 25, 2000. 
then explains how the development of international human rights law after World War II led U.S. treatymakers to embrace the particular RUDs that are the focus of this Article. Part I.C describes these RUDs in detail.

\section{A. A Brief History of Conditional Consent}

The U.S. treatymaking process operates essentially as follows. ${ }^{15}$ Representatives of the President negotiate the terms of the treaty with foreign nations, and the President or his representative signs the completed draft. ${ }^{16}$ The President then transmits the treaty to the Senate for its advice and consent. If the treaty receives the required twothirds vote, the Senate sends a resolution to the President approving the treaty. ${ }^{17}$ The President has the discretion at this point to ratify or not ratify the treaty. ${ }^{18}$ Ratification is the act by which a nation formally declares its intent to be bound by a treaty. When the President signs the instrument of ratification and the Secretary of State affixes the Seal of the United States, the U.S. ratification process is complete. Even at this point, however, the United States is not bound by the terms of the treaty. The treaty only becomes binding on the United States when the instrument of ratification is either exchanged, as is usually the process with respect to bilateral treaties, or deposited at a specified place, as is usually the process with respect to multilateral treaties. $^{19}$

On numerous occasions throughout U.S. history, the President and Senate have proposed conditions in connection with their ratification of treaties. Indeed, approximately fifteen percent of all Article II treaties since the Founding have been ratified subject to conditions that require subsequent assent from other treaty parties. ${ }^{20}$ Usually the Senate has proposed these conditions, but sometimes the President has as well. ${ }^{21}$ The treatymakers have used a variety of labels for these

${ }^{15}$ See CONGRESSIONAL RESEARCH SERV., TREATIES AND OTHER INTERNaTIONAL Agreements: THE ROLE OF THE UNITEd STATES SENATE, 103d Cong., 1st Sess., at 75120 (1993) [hereinafter CRS STUDY] (describing the various stages of the U.S. treatymaking process).

${ }^{16}$ Id. at $69-70$.

17 Id. at 107.

18 Id. at 109.

19 Id. at 83-86.

${ }^{20}$ Kevin C. Kennedy, Conditional Approval of Treaties by the U.S. Senate, 19 LOX. L.A. INT'L \& COMP. L.J. 89, 91,97 (1996).

${ }^{21}$ CRS STUDY, supra note 15, at 96-98; GEORGE H. HAYNES, THE SENATE OF THE UNITED STATES 609-10 (1938). 
conditions, including "amendment," "reservation," "understanding," "declaration," and "proviso." most important forms of conditional consent, whatever their labels, have been the power not to consent to particular treaty terms, the power to consent to a treaty on the condition that it has no domestic force in the absence of congressional implementation, and the power to take account of the United States's federal structure in negotiating and implementing a treaty.

Consider first the treatymakers' power not to consent to particular treaty terms. There is no question that the President's "Power ... to make Treaties" ${ }^{23}$ entails the power to withhold consent to particular treaty terms. Without the power to condition consent on the negotiating partner's acceptance of proposed terms, the President would lack the power to negotiate. This is why the President has, since our nation's beginning, exercised the power to refuse to agree to particular treaty terms. The President has always exercised plenary discretion in this regard, and it has always been understood that he can decline to ratify a treaty for any reason, even after the Senate has given its advice and consent. ${ }^{2 *}$

The Senate too has always exercised the power not to consent to particular treaty terms, but it has exercised this power in a different way and for different reasons. ${ }^{25}$ The Senate's power to "consent" entails the power to block ratification of a treaty by withholding its consent. Since the 1790 s, this greater power to withhold consent altogether has been viewed as including the lesser power to consent to some provisions of the treaty but not others. The exercise of the conditional consent power has been in part a response by the Senate to its loss of any substantial "advice" role in the treaty process. Many of the Founders believed that the advice function required that the President consult with the Senate prior to negotiating and signing a treaty. ${ }^{2 ;}$ During the Washington administration, however, this process

"Under international law, treaty conditions, regardless of how they are labeled by particular nations, are considered "reservations" if they "purport[] to exclude or to modify the legal effect of certain provisions of the treaty in their application to that State." Vienna Convention on the Law of Treaties, May 23, 1969, art. 2(1)(d), 1155 U.N.T.S. 331, 333, 8 I.L.M. 679, 681 [hereinafter Vienna Convention].

2 U.S. CONST. art. II, $\$ 2, \mathrm{cl} .2$.

2 See LOUTS HENKIN, FOREIGN AFFAIRS AND THE UNITED STATES CONSTITUTION 184 (2d ed. 1996) ("Once the Senate has consented, the President is free to make (or not to make) the treaty and the Senate has no further authority in respect of it.").

25 See CRS STUDY, supra note 15, at 102-04.

" RALSTON Hayden, The SENATE AND TREATIES, 1789-1817, at 18-20 (1920); Ar- 
proved unwieldy, and the President began to submit treaties to the Senate without prior consultation. ${ }^{27}$ Since then, the Senate has not played a substantial role in advising the President in connection with treaty negotiations. ${ }^{28}$ In order to preserve its ability to advise regarding treaty terms, the Senate instead began the practice of conditioning its consent on amendments to the negotiated treaty. ${ }^{29}$

The first example of such conditional consent by the Senate occurred in connection with the Jay Treaty with Great Britain. ${ }^{30}$ This treaty, negotiated by John Jay in 1794, was designed to resolve a variety of compensation, trade, and boundary disputes between the United States and Great Britain. The treaty was controversial in the United States due to concerns that the Washington administration had made too many concessions to the British. A bare two-thirds of the Senate gave their advice and consent to the treaty in 1795 , but only on the condition that an article of the treaty reserving to Great Britain the right to restrict trade between the United States and the British West Indies be suspended. ${ }^{31}$ Britain accepted this condition without complaint, and the treaty was ratified. ${ }^{32}$ A few years later, the Senate gave its advice and consent to a treaty with Tunisia on the condition that an

thur Bestor, "Advice" From the Very Beginning, "Consent" When the End Is Achieved, 83 AM. J. INT'L L. 718 (1989); Jack N. Rakove, Solving a Constitutional Puzzle: The Treatymaking Clause as a Case Study, I PERSPS. IN AM. HIST. 233, 257 (1984).

${ }^{27}$ HAYDEN, supra note 26, at 11-16.

${ }^{28}$ See RESTATEMENT (THIRD) OF THE FOREIGN RELATIONS LAW OF THE UNTTED STATES $\$ 303$, reporters' note 3 (1987). Although it generally has not had a significant advice role in the treaty process, the Senate is sometimes involved in the treaty process before and during the negotiation stage. The Senate sometimes proposes subjects for treatymaking and approves treaty negotiators, and sometimes individual senators are part of the negotiating team. CRS STUDY, supra note 15, at 69-81.

${ }^{29}$ See CRS STUDY, supra note 15, at 96; SAMUEL B. CRANDALl, TREATIES, THEIR MAKING AND ENFORCEMENT 70 (1904); HAYDEN, supra note 26, at 110-11; HENKIN, supra note 24, at 180 .

${ }^{30}$ Treaty of Amity, Commerce and Navigation, Nov. 19, 1794, U.S.-Gr. Brit., 8 Stat. 116. For a discussion of the historical events surrounding the Jay Treaty, see STANLEY ELKINS \& ERIC MCKIrRICK, THE AGE OF FEDERALISM, 375-449 (1993).

${ }^{31}$ The Senate stated that it was consenting to the treaty:

on condition that there be added to the said treaty an article whereby it shall be agreed to suspend the operation of so much of the 12th article, as respects the trade which his said Majesty thereby consents may be carried on, between the United States and his islands in West Indies.

SENATE EXEC. JOURNAL, 4TH CONG., Special Sess., June 24, 1795, at 186.

${ }^{32}$ HAYDEN, supra note 26, at 87; HAYNES, supra note 21, at 607-08. The Senate also began attaching interpretive conditions to its consent early in U.S. history. For example, in consenting to a 1796 treaty between the United States and the Creek Indians, the Senate stated that provisions in the treaty allowing the federal government to establish military and trading posts in the Creeks's territory should not be construed to preempt rights Georgia had been claiming in this land. HAYDEN, supra note 26, at 99. 
article in the treaty be suspended and renegotiated, and the article was in fact renegotiated prior to ratification. ${ }^{33}$ The Senate again exercised its conditional consent power in connection with an 1800 treaty between the United States and France. ${ }^{34}$

The United States's treaty partners did not always respond favorably to the Senate's conditions. In negotiating an 1803 boundary treaty with the United States, Great Britain would not accept the amendment proposed by the Senate, and the treaty was never ratified. ${ }^{35}$ The head of the British Foreign Office at that time criticized the United States's conditional consent practice, calling it "new, unauthorized and not to be sanctioned." Great Britain similarly complained about conditions proposed by the Senate in connection with an 1824 treaty concerning the African slave trade. ${ }^{37}$ Over time, however, this practice became generally accepted by the international community. ${ }^{38}$ The United States engaged in this practice in connection with numerous treaties during the nineteenth and early twentieth centuries, generally without controversy, as did many of its treaty partners. ${ }^{39}$ This practice of not consenting to particular treaty terms has continued to the present day.

The second type of conditional consent of importance to this Ar-

is Treaty of Amity, Commerce, and Navigation, Aug. 28, 1797, U.S.-Tunis., T.S. No. 360 , at $1088 \mathrm{n} .1$. The article in question provided for the imposition of customs duties to be paid by citizens of each country upon goods carried into the other country. Among other things, the Senate objected to this article on the ground that it violated most favored nation clauses in treaties the United States had with other nations. HIIDEN, supra note 26, at 109-11.

"The Senate gave its consent on the conditions that one of the articles of the treaty be expunged and that the operation of the treaty be limited to a period of eight years from the time of the exchange of ratifications. HAYDEN, supra note 26, at 121. This treaty was subsequently ratified subject to the Senate's conditions. Id. at 123-24.

${ }^{35}$ The treaty was the King-Hawkesbury Convention. The proposed amendment would have deleted an article of the treaty that the Senate was worried might interfere with U.S. rights in the newly purchased Louisiana Territory. HAYDEN, supra note 26, at 145-56.

Id. at 150 .

${ }^{17} 5$ JOHN BASSETT MOORE, A DIGEST OF INTERNATIONAL LAW $\$ 748$, at 200 (1906). In response, then-Secretary of State Henry Clay reminded Great Britain that the Senate's conditional consent power was a function of the constitutional division of the treaty power between the President and the Senate and that this was something that "the government of the United States has always communicated to the foreign powers with which it treats, and to none more fully than to the United Kingdom of Great Britain and Ireland." ROBERT T. DEVIIN, THE TREATY POWER UNDER THE CONSTITUTION OF THE UNITED STATES $\$ 64$, at 61-62 n.18 (1908).

See HAYDEN, supra note 26 , at 156.

For examples, see DAVID HUNTER MILLER, RESERVATIONS TO TREATIES: THEIR EFFECT AND THE PROCEDURE IN REGARD THERETO (1919). 
ticle is the power to render the treaty without domestic force unless and until Congress enacts federal implementing legislation. Although the particular "non-self-execution" clauses attached to human rights treaties appear to be a modern phenomenon, the proposition that treaties and other federal laws may be non-self-executing has been well established throughout U.S. history. ${ }^{40}$ Moreover, there are at least two longstanding precursors to the modern non-self-execution clauses. ${ }^{41}$ First, in a number of instances in the nineteenth and early twentieth centuries, U.S. treatymakers consented to treaties on the condition that the treaties, or particular articles in the treaties, would take effect only after Congress passed legislation implementing them. ${ }^{42}$ These conditions were, in essence, international non-selfexecution clauses. They differed from the modern non-self-execution clauses in that they prevented the treaty provisions from binding the United States until Congress acted, whereas the modern non-selfexecution clauses simply prevent the treaty provisions from being enforced in U.S. courts until Congress acts. Nevertheless, these conditions were designed to accomplish precisely the same goal as the modern non-self-execution clauses: inclusion of the House of Representatives in the domestic implementation of treaties. ${ }^{48}$

Another precursor to the modern non-self-execution clauses were the instances, dating back to at least the late 1800s, in which the United States expressly reserved certain treaty implementation issues

${ }^{40}$ See infra notes 216-19 and accompanying text.

${ }^{41}$ Many of the following examples can be found in Louis Henkin, The Treaty Makers and the Law Makers: The Niagara Reservation, 56 CoLUM. L. REV. 1151 (1956).

${ }_{42}$ These conditions were especially common in connection with bilateral trade agreements because of the concern that the Constitution might require that changes in U.S. import duties originate in the House of Representatives. See 1 WESTEL W. WILLOUGHBY, THE CONSTITUTIONAL LAW OF THE UNTTED STATES 558-60 (2d ed. 1929). For example, an 1854 trade treaty with Great Britain provided that it would not take effect until the U.S. Congress and the British Parliament enacted "laws required to carry it into operation." Reciprocity Treaty with Great Britain, June 5, 1854, U.S.-Gr. Brit, art. 5, 10 Stat. 1089, 1092. Similarly, a provision in an 1875 trade treaty with Hawaii stated that the treaty would not take effect "until a law to carry it into operation shall have been passed by the Congress of the United States of America." Convention between the United States of America and His Majesty the King of the Hawaiian Islands, Jan. 30, 1875, U.S.-Hawaii, art. V, 19 Stat. 625, 627. Additionally, in a 1902 trade treaty with Cuba, the Senate added an amendment stating that the Convention "shall not take effect until the same shall have been approved by the Congress." Commercial Convention between the United States and Cuba, Dec. 11, 1902, U.S.-Cuba, art. 11, 33 Stat. 2136, 2142. The Supreme Court subsequently gave effect to the Senate's amendment of the Cuba treaty in United States v. American Sugar Refining Co., 202 U.S. 563 (1906).

${ }^{43}$ See Wirloughis, supra note 42 , at 558. 
for Congress. For example, in an 1899 treaty with Spain concerning the acquisition of Puerto Rico and the Philippines, the U.S. treatymakers included a provision stating that " $[t]$ he civil rights and political status of the native inhabitants of the territories hereby ceded to the United States shall be determined by the Congress." Similarly, the Senate gave its advice and consent to a 1920 treaty with Austria with the stipulation that the United States would not be represented in or participate in any international body authorized by the treaty "unless and until an Act of the Congress of the United States shall provide for such representation or participation."

A third type of conditional consent of relevance to this Article concerns the United States's federal structure of government. Throughout U.S. history, the treatymakers have used their conditional consent powers to guard against undue intrusions on state prerogatives. At times, they have limited the substantive terms of treaties to protect state interests. ${ }^{46}$ At other times, they have made treaties dependent on state law, ${ }^{47}$ or have expressly limited U.S. treaty obligations

14 Treaty of Peace Between the United States of America and the Kingdom of Spain, Dec. 10, 1898, U.S.-Spain, art. IX, 30 Stat. 1754, 1759. Several Supreme Court Justices expressly endorsed the validity of this provision. See Downes v. Bidwell, 182 U.S. 244, 340-41 (1901) (White, J., concurring). The entire Court referred to it approvingly in dicta in Dorr $v$. United States, 195 U.S. 138, 143 (1904). See also Fourteen Diamond Rings v. United States, 183 U.S. 176, 182, $184-85$ (1901) (Brown, J., concurring) (stating that there was "no doubt" that the U.S. treatymakers could provide that customs relations between territories ceded by treaty and the United States "should remain unchanged until legislation had been had upon the subject").

4 Treaty of Peace Between the United States and Austria, Aug. 24, 1921, U.S.-Aus., 42 Stat. 1946, 1949. An identical provision was included in a post-World War I peace treaty with Germany. Treaty of Peace Between the United States and Germany, Aug. 25, 1921, U.S.-F.R.G., 42 Stat. 1939, 1945. Another example of an early twentieth century condition designed to limit a treaty's domestic effect was a statement by the Senate in consenting to a 1911 Treaty of Commerce and Navigation with Japan that the treaty "shall not be deemed to repeal or affect any of the provisions" in a specified immigration statute. MILLER, supra note 39 , at 60-63.

"'See, e.g., Ralston Hayden, The States' Rights Doctrine and the Treaty-Making Power, 22 AM. HIST. REV. 566, 585 (1917) (explaining that, between 1830 and 1860, "the Senate and the executive entertained grave and increasing doubts concerning their authority to make treaties" concerning rights to real property and that "in every particular instance in which conflict arose the treaty in question was amended to bring it more nearly' into accord with the states' rights theory").

17. See, e.g., Consular Convention Between the United States of America and His Majesty the Emperor of the French, Feb. 23, 1853, U.S.-Fr., art. VII, 10 Stat. 992, 996 (allowing French citizens to possess land equally with U.S. citizens "[i]n all the States of the Union whose existing laws permit it, so long and to the same extent as the said laws shall remain in force" and promising that the President would "recommend to [other states] the passage of such laws as may be necessary for the purpose of conferring this right"). 
to matters "within the jurisdiction' of the federal government." federalism clauses attached by the treatymakers to the U.S. ratification of modern human rights treaties reflect this tradition.

In sum, since the early days of the nation, the President and the Senate have attached a variety of conditions to their consent to treaties. No court has ever invalidated these conditions. On the contrary, the Supreme Court has referred to the treatymakers' conditional consent power approvingly in several decisions, ${ }^{49}$ and the state courts and lower federal courts have almost uniformly given effect to these conditions. $^{50}$

\section{B. Human Rights Treaties and the Bricker Amendment Debates}

Before World War II, international law primarily regulated interactions among nations, and it did not contain extensive protections for individual rights. ${ }^{51}$ Soon after the War, with the experience of the Holocaust and other atrocities fresh in mind, the international community began to develop a comprehensive body of international human rights law. The seeds of this human rights law revolution were sown in the 1940s. The United Nations Charter, which came into force in 1945, contained general commitments to protect human rights. ${ }^{52}$ Three years later, the United Nations General Assembly adopted the Convention on the Prevention and Punishment of the Crime of Genocide ${ }^{53}$ and opened it for national ratifications. That

${ }^{48}$ HENKN, supra note 24, at 192 n.*; Henkin, supra note 4 , at 345.

49 In addition to the decisions cited supra notes 42 and 44 , see James v. Dravo Contracting Co., 302 U.S. 134, 148 (1937) (noting that "it is familiar practice for the Senate to accompany [its consent to treaties] with reservations"); Haver v. Yaker, 76 U.S. (9 Wall.) 32, 35 (1869) (noting that the Senate is "not required to adopt or reject [a treaty] as a whole, but may modify or amend it"). See also United States v. Stuart, 489 U.S. 353, 37475 (1989) (Scalia, J., concurring) ("[The Senate] . . . may, in the form of a resolution, give its consent [to a treaty] on the basis of conditions."); Fourteen Diamond Rings, 183 U.S. at 183 (Brown, J., concurring) ("The Senate ... may refuse its ratification, or make such ratification conditional upon the adoption of amendments to the treaty.").

${ }^{50}$ For recent citations, see supra note 6 . The only judicial decision suggesting limits on the conditional consent power is Power Authority of New York v. Federal Power Commission, 247 F.2d 538 (D.C. Cir. 1957), vacated and remanded with directions to dismiss as moot sub nom. American Public Power Association v. Power Authority of New York, 355 U.S. 64 (1957), discussed infra text accompanying notes 236-46.

${ }^{51}$ For discussions of pre-World War II international law protections for human rights, see LOUIS HENKIN, INTERNATIONAL LAW: POLITICS AND VALUES 169-73 (1995); STEPHEN D. KRASNER, SOVEREIGNTY: ORGANIZED HYPOCRISY 73-126 (1999).

${ }^{52}$ U. N. CHARTER art. 1, para. 3.

${ }^{53}$ Dec. 9, 1948, 78 U.N.T.S. 277. 
same year, the General Assembly issued its nonbinding, but nonetheless influential, Universal Declaration of Human Rights. ${ }^{54}$ The Universal Declaration, which aspired to be a "common standard of achievement for all peoples and all nations, ${ }^{, 55}$ contained broadly worded civil, political, economic, social, and cultural rights. Immediately following the passage of the Declaration, the United Nations Commission on Human Rights began drafting a human rights covenant that aimed to convert the nonbinding provisions of the Declaration into binding treaty obligations. ${ }^{56}$

United States officials played a prominent role in creating the emerging international regime of human rights law. Nonetheless, there were intense debates in the United States during the 1950s over whether and to what extent the nation should participate in this regime. $^{57}$ These debates focused principally on the domestic implications of ratifying the human rights treaties. Some people were concerned that the U.N. Charter's human rights provisions would give Congress the power to enact civil rights legislation otherwise beyond its constitutional powers. ${ }^{58}$ This was a plausible belief in light of the Supreme Court's decision in Missouri v. Holland, which held that, when implementing a treaty, Congress is not subject to the federalism limitations applicable to the exercise of its Article I powers. ${ }^{59}$ A related concern was that the U.N. Charter would preempt state laws by virtue of the Supremacy Clause. ${ }^{60}$ In fact, this argument was seemingly endorsed by one lower California court and four justices of the U.S. Supreme Court in their consideration of the validity of a California alien land ownership statute. ${ }^{61}$ The potentially self-executing nature

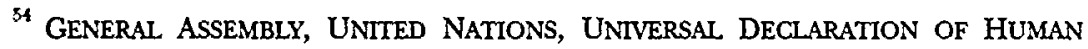
RIGHTS, U.N. Doc. A/810, U.N. Sales No. 1952.1.15 (1952) [hereinafter UNIVERSAL DECLARATION].

${ }^{55}$ Id. para. 8.

${ }^{50}$ This drafting process would eventually lead to the promulgation of two human rights treaties-the Covenant on Civil and Political Rights, and the Covenant on Economic, Social, and Cultural Rights. See LELAND M. GOODRICH, ThE UNITEd NaTIONS 247-53 (1959) (describing the transition from the nonbinding Declaration to the obligations of the covenants).

${ }^{57}$ See generally Natalie HeVENER KaUfMaN, Human RIGHTS TREATIES AND THE Senate (1990); Duane Tananbaum, The Bricker Amendment Controversy: A TEST OF EISENHOWER'S POLITICAL LEADERSHIP (1988).

${ }^{58}$ See generally TANANBAUM, supra note 57.

252 U.S. 416, 433 (1920).

4) TANANBAUM, supra note 57, at 1-15.

"1 See Oyama v. California, 332 U.S. 633, 649 (1948) (Black, J., concurring, joined by Douglas, J.); id. at 673 (Murphy, J., concurring, joined by Rutledge, J.); Sei Fujii v. State, 217 P.2d 481, 487 (Cal. Dist. Ct. App. 1950), vacated, 242 P.2d 617 (Cal. 1952). 
of the Charter was particularly worrisome to some in the early days of the anticommunist Cold War period because the Universal Declaration, including its very progressive provisions concerning economic, social, and cultural rights, ${ }^{62}$ was described by its proponents as giving content to the vague human rights provisions of the U.N. Charter. ${ }^{63}$

Another event that triggered concerns in the United States was President Truman's submission of the Convention on the Prevention and Punishment of the Crime of Genocide to the Senate in 1948. Although the United States had helped to draft the Convention and supported an international prohibition on genocide, many senators and others worried about the domestic consequences of ratifying the treaty. One of their central concerns was the vagueness of the Convention's definition of "genocide." The Convention defined genocide to include certain acts "committed with intent to destroy" covered groups, including the act of causing "mental harm" to members of covered groups. ${ }^{64}$ The unease over these definitional provisions related to their possible inconsistency with the First Amendment, their potential use as a basis for prosecuting U.S. military officials abroad, and their foreseeable use in support of a claim that U.S. policies toward African-Americans and Native Americans constituted genocide. ${ }^{6.5}$ There was also a more general concern about the erosion of U.S. sovereignty and independence. ${ }^{66}$

These various concerns led to proposals in the 1950s to amend the Constitution to limit the treaty powers of the United States. ${ }^{67}$ Along with leaders of the American Bar Association, a key proponent of such an amendment was Senator John Bricker of Ohio, and the various proposed amendments are commonly referred to jointly as the "Bricker Amendment." In general, the proposed amendments were intended to preclude treaties from being self-executing and to make clear that treaties would not override the reserved powers of the

62 The Declaration states, among other things, that "[e]veryone" has the right to employment, to equal pay for equal work, to membership in trade unions, to an adequate standard of living, to an education, and to participation in the cultural life of the community. UNIVERSAL DECLARATION, supra note 54, arts. 23-27.

${ }^{68}$ In fact, the lower court's decision in Sei Fujii relied on the Universal Declaration in interpreting the meaning of the United Nations Charter. 217 P.2d at 487-88.

${ }^{64}$ Convention on the Prevention and Punishment of the Crime of Genocide, Dec. 9, 1948, art. II, 78 U.N.T.S. 277 (emphasis added) [hereinafter Genocide Convention].

${ }^{65}$ For a summary of the lengthy congressional hearings in which these and other concerns were articulated, see KAUFMAN, supra note 57, at 42-59.

${ }^{66} I d$.

67 See generally TANANBAUM, supra note 57.

${ }^{68}$ Id. 
states. $^{6}$ Some versions also would have restricted the use of executive agreements." There was substantial consideration of these proposals during the 1950s. ${ }^{71}$ In fact, one of the proposed amendments fell only one vote short of obtaining the necessary two-thirds vote in the Senate. ${ }^{72}$

To help defeat the Bricker Amendment, the Eisenhower administration made a commitment that it would not seek to become a party to any more human rights treaties. ${ }^{73}$ Secretary of State John Foster Dulles announced during the Bricker Amendment hearings in 1953 that the administration had no intention of becoming a party to the then-proposed human rights treaties. ${ }^{74}$ In 1955, Dulles reaffirmed that "the United States will not sign or become a party to the covenants on human rights, the convention on the political rights of women, and certain other proposed multilateral agreements. ${ }^{, 75}$ In the same year, the State Department published a circular stating, in obvious reference to the Bricker Amendment debate, that " $[t]$ reaties are not to be used as a device for the purpose of effecting internal social changes or to try to circumvent the constitutional procedures established in relation to what are essentially matters of domestic concern." For decades thereafter, presidents did not submit major human rights treaties to the Senate (although they did continue to seek the Senate's advice and consent for the Genocide Convention) ${ }^{77}$

"For example, some versions of the Bricker Amendment provided that "[a] treaty shall become effective as internal law in the United States only through legislation which would be valid in the absence of treaty." S.J. Res. 130, 82d Cong. $\$ 2$ (1952).

"For example, some versions of the Bricker Amendment provided that "[e]xecutive agreements shall not be made in lieu of treaties." S.J. Res. 102, 82d Cong. $\$ 4(1951)$.

${ }^{21}$ See, e.g., Treaties and Executive Agreements: Hearings on S.J. Res. 1 and S.J. Res. 43 Before a Subcomm. of the Senate Comm. on the Judiciary, 83d Cong. (1953) [hereinafter 1953 Hearings].

100 CONG. REC. 2251 (1954); TANANBAUM, supra note 57, at 180.

7. KAUFMAN, supra note 57, at 104-05; TANANBAUM, supra note 57, at 89, 199.

741953 Hearings, supra note 71 , at 825 (statement of Secretary Dulles). During these hearings, executive branch officials also assured the Senate that it had the power to give its consent to human rights treaties on the condition that they would be nonself-executing. Id. at 922 (testimony of Attorney General Brownell).

32 DEP'T ST. BuLl. 820, 822 (1955).

"' U.S. State Dep't Circular No. 175, I 2 (Dec. 13, 1955), reprinted in 50 AM. J. INT'L L. 784,785 (1956).

${ }^{77}$ The United States did ratify three less-controversial human rights treaties between the time of the Bricker Amendment controversy and the Carter administration: the Supplementary Convention on the Abolition of Slavery, the Slave Trade, and Institutions and Practices Similar to Slavery, opened for signature Sept. 7, 1956, 18 U.S.T. 3201, 266 U.N.T.S. 3; the Convention on the Political Rights of Women, opened for sig- 
This reticence changed with the Carter administration, which submitted a package of human rights treaties to the Senate in the late 1970 s. $^{78}$ Since that time, every President has urged the Senate to approve the ratification of major human rights treaties, and the Senate has in fact given its advice and consent to four such treaties. ${ }^{79}$ With respect to the treaties to which the Senate has given its advice and consent, there has been a remarkable consensus across very different administrations and very different Senates about both the desirability of ratifying these treaties and the need to attach RUDs to the treaties as a condition of ratification to protect domestic prerogatives.

As for the desirability of ratifying human rights treaties, presidents and the Senate have agreed that a failure by the United States to ratify the major human rights treaties would result in at least two kinds of foreign policy costs. First, nonratification would preclude the United States from participating in the treaty-related institutions that, in turn, influence the course of international human rights law. ${ }^{80}$ Second, nonratification would create a "troubling complication" in U.S. diplomacy, namely, that the United States could not credibly encourage other nations to embrace human rights norms if it had not itself embraced those norms. ${ }^{81}$

Presidents and the Senate have also agreed, however, that the modern human rights treaties implicate serious countervailing considerations reminiscent of the Bricker Amendment debates. These concerns are easiest to understand with respect to the most ambitious of these treaties, the International Covenant on Civil and Political Rights ("ICCPR"). The ICCPR contains dozens of vaguely worded rights guarantees that differ in important linguistic details from the

nature Mar. 31, 1953, 27 U.S.T. 1909, 193 U.N.T.S. 135; and the Inter-American Convention on the Granting of Political Rights to Women, May 2, 1948, 27 U.S.T. 3301, O.A.S.T.S. No. 3.

${ }^{78}$ In 1978, the Carter Administration transmitted four human rights treaties to the Senate: the International Convention on the Elimination of All Forms of Racial Discrimination, Mar. 7, 1966, 660 U.N.T.S. 195; the International Covenant on Economic, Social and Cultural Rights, opened for signature Dec. 19, 1966, 993 U.N.T.S. 3; the International Covenant on Civil and Political Rights, opened for signature Dec. 19, 1966, 999 U.N.T.S. 171; and the American Convention on Human Rights, Nov. 22, 1969, 1144 U.N.T.S. 123. In 1980, the Administration transmitted to the Senate the Convention on the Elimination of All Forms of Discrimination Against Women, opened for signature Mar. 1, 1980, 1249 U.N.T.S. 13.

${ }^{79}$ See infra note 86.

*oe, e.g., Four Treaties Relating to Human Rights, Hearings before the Comm. on Foreign Relations, 96th Cong. 21 (1979) [hereinafter 1979 Hearings] (testimony of Deputy Secretary of State Warren Christopher concerning ICCPR).

Si See, e.g., id. 
analogous guarantees under U.S. domestic law. ${ }^{82}$ Some of these provisions arguably conflict with U.S. constitutional guarantees. ${ }^{83}$ In addition, the ICCPR, if self-executing, would have the same domestic effect as a congressional statute and thus would supersede inconsistent state law and prior inconsistent federal legislation. There was concern that, even if courts ultimately decided that each of the differently worded provisions in the ICCPR did not require a change in domestic law, litigation of these issues would be costly and would generate substantial legal uncertainty. ${ }^{84}$ These concerns also arose, although on a narrower scale, with respect to the other human rights treaties.

To address these concerns, President Carter and every subsequent President have included proposed RUDs with their submission of human rights treaties to the Senate. ${ }^{85}$ The Senate has given its advice

"For example, the ICCPR bars "arbitrary arrest or detention," requires that anyone arrested "shall be promptly informed of any charges against him," protects against "arbitrary... interference with ... privacy, family, home or correspondence," guarantees that everyone "shall have the right to freedom of thought, conscience and religion," requires that the law give "effective protection against discrimination on any ground such as race, color, sex, language, religion, political or other opinion, national or social origin, property, birth or other status," guarantees the "equal right of men and women to the enjoyment of all civil and political rights," guarantees "the inherent right to life," ensures that "[a]ll persons deprived of their liberty shall be treated with humanity and with respect for the inherent dignity of the human person," guarantees the "right to hold opinions without interference," secures "the right to freedom of association with others, including the right to form and join trade unions," prohibits "torture or ... cruel, inhuman or degrading treatment or punishment," and guarantees the "right of self-determination[, including the right] freely [to] determine [one's] political status and freely pursue their economic, social and cultural development." ICCPR, supra note 10, arts. 6-18, 999 U.N.T.S. at 17478.

"See, e.g., 1979 Hearings, supra note 80, at 30 (testimony of President Carter's State Department Legal Advisor, Roberts Owen).

St See, e.g., id. at 40 (testimony of Jack Goldklang, Department of Justice) ("If the treaties were directly enforceable in court, the court would have the difficult job of trying to reconcile how these four treaties fit together with existing [U.S. law].").

President Reagan proposed RUDs in submitting the Convention Against Torture and Other Cruel, Inhuman or Degrading Treatment or Punishment, opened for signature Dec. 10, 1984, 23 I.L.M. 1027 [hereinafter Torture Convention], and in resubmitting the Genocide Convention; President Bush did the same in resubmitting the Torture Convention and the International Covenant on Civil and Political Rights; and President Clinton proposed RUDs when he resubmitted the Race Convention. In addition, presidents have proposed RUDs for several human rights treaties that the United States has signed but not yet ratified, including the American Convention on Human Rights, the International Covenant on Economic, Social, and Cultural Rights, and the Convention on the Elimination of All Forms of Discrimination Against Women. See Convention on the Elimination of All Forms of Discrimination Against Women, S. ExEC. REP. 103-38, at 5 (1994); Message from the President of the United States Transmitting Four Treaties Pertaining to Human Rights, S. EXEC. Doc. No. 952, at viii-xi (1978) (describing the International Covenant on Economic, Social and 
and consent to, and the United States has ratified, four of these treaties: the Genocide Convention, ratified in 1988; the ICCPR, ratified in 1992; the Torture Convention, ratified in 1994; and the Convention on the Elimination of All Forms of Racial Discrimination, also ratified in 1994. The United States included RUDs in the ratification instruments for each of these treaties as a precondition of U.S. ratification. ${ }^{86}$ The Senate usually consented to the RUDs in the form proposed by the President, but sometimes the Senate modified them slightly or requested that the President modify them. ${ }^{87}$

\section{G. An Overview of Modern RUDs}

RUDs are designed to harmonize the treaties with existing requirements of U.S. law and to leave domestic implementation of the treaties to Congress. They cover a variety of subjects and take a variety

Cultural Rights); Human Rights Treaties: Message to the Senate, 14 WEEKLY COMP. PRES. DOC. 395 (Feb. 23, 1978) (transmitting human rights treaties to the Senate and recommending consent to their ratification). President Carter was not the first to propose conditions along with a human rights treaty. As early as 1950 , understandings and declarations had been proposed in connection with the Genocide Convention. See KAUFMAN, supra note 57, at 206 (listing attachments proposed by the Senate Foreign Relations Committee for the Genocide Convention); see also id. at 197 ("Reservations have been a key component of human rights treaties from the earliest consideration of the Genocide Convention.").

${ }^{86}$ See U.S. Senate Resolution of Advice and Consent to Ratification of the Convention on the Elimination of All Forms of Racial Discrimination, 140 CONG. REC. S14326 (daily ed. June 24, 1994) [hereinafter U.S. RUDs to Race Convention]; U.S. Senate Resolution of Advice and Consent to Ratification of the International Covenant on Civil and Political Rights, 138 CONG. REC. S4783 (daily ed. Apr. 2, 1992) [hereinafter U.S. RUDs to ICCPR]; U.S. Senate Resolution of Advice and Consent to Ratification of the Convention Against Torture and Other Cruel, Inhuman or Degrading Treatment or Punishment, 136 CoNG. REC. S17491 (daily ed. Oct. 27, 1990) [hereinafter U.S. RUDs to Torture Convention]; U.S. Senate Resolution of Advice and Consent to Ratification of the Convention on the Prevention and Punishment of the Crime of Genocide, 132 CONG. REC. S1378 (daily ed. Feb. 19, 1986) [hereinafter U.S. RUDs to Genocide Convention]. The text of these RUDs is available at the University of Minnesota's excellent human rights library web site, http://wwwl.umn.edu/humanrts/usdocs/ usres.html.

${ }^{87}$ The Reagan Administration's proposed RUDs to the Torture Convention were criticized by some senators and human rights groups as being too restrictive. In light of this criticism, as well as a special request from the Senate Foreign Relations Committee, the Bush Administration submitted a revised and less restrictive set of RUDs. SENATE COMM. ON FOREIGN RELATIONS, REPORT ON THE CONVENTION AGAINST TORTURE AND OTHER CRUEL, INHUMAN, OR DEGRADING TREATMENT OR PUNISHMENT, S. EXEC. REP. NO. 101-30, at 4 (2d Sess. 1990); see also S. EXEC. REP. No. 101-30 app. A (2d Sess. 1990) (letter from Janet G. Mullins, Assistant Secretary, Legislative Affairs, Department of State, to Senator Claiborne Pell, transmitting Bush Administration Reservations, Understandings and Declarations). 
of forms. For purposes of analysis, they can be grouped into five categories:

Substantive Reservations. Some RUDs are reservations pursuant to which the United States declines to consent altogether to certain provisions in the treaties. These reservations are very much the exception to the rule; for each of the four human rights treaties under consideration, the United States consented to a large majority of the provisions. Some substantive reservations are based on potential conflicts between treaty provisions and U.S. constitutional rights. For example, First Amendment concerns led the United States to decline to agree to restrictions on hate speech in the Race Convention "to the extent that [such speech is] protected by the Constitution and laws of the United States. ${ }^{\prime 88}$ Similarly, the United States attached a reservation to its ratification of the ICCPR, stating that the ICCPR's restriction on propaganda for war and hate speech "does not authorize or require legislation or other action by the United States that would restrict the right of free speech and association protected by the Constitution and laws of the United States. ${ }^{89}$

Other substantive reservations are based not on a constitutional conflict but rather on a political or policy disagreement with certain provisions of the treaties. For example, the United States attached to its ratification of the ICCPR reservations allowing it to impose criminal punishment consistent with the Fifth, Sixth, and Eighth Amendments, including capital punishment of juvenile offenders, notwithstanding limitations on such punishment in the ICCPR ${ }^{90}$ The United

${ }^{* *}$ U.S. RUDs to Race Convention, supra note 86, para. I(1), at S14326.

U.S. RUDs to ICCPR, supra note 86 , para. I(1), at S4783. With respect to the Genocide Convention, the United States sought to protect First Amendment interests by attaching a reservation stating that "[n]othing in this Convention requires or authorizes legislation or other action by the United States of America prohibited by the Constitution of the United States as interpreted by the United States." U.S. RUDs to the Genocide Convention, supra note 86, para. I(2), at S1378; see also REPORT OF THE COMAITTEE ON FOREIGN RELATIONS, INTERNATIONAL CONVENTION ON THE PREveNTION AND PUNISHMENT OF THE CRIME OF GENOCIDE, S. EXEC. REP. No. 99-2, at 20-21 (1985) [hereinafter GENOCIDE CONTENTION REPORT] (explaining that this reservation was designed primarily to avoid conflict with the First Amendment).

'"' Article 6(5) of the ICCPR provides that "[s]entence of death shall not be imposed for crimes committed by persons below eighteen years of age and shall not be carried out on pregnant women" and Article 7 provides that "[n]o one shall be subjected to torture or to cruel, inhuman or degrading treatment or punishment." ICCPR, supra note 10, arts. 6(5), 7, 999 U.N.T.S. at 175. The pertinent U.S. RUDs provided that "the United States reserves the right, subject to its Constitutional constraints, to impose capital punishment on any person (other than a pregnant woman) duly convicted under existing or future laws permitting the imposition of capital pun- 
States attached a similar reservation with respect to limitations on punishment in the Torture Convention..$^{91}$ It also attached a condition to its ratification of the Race Convention making clear that it was not agreeing to modify the traditional public/private distinction in U.S. civil rights law. ${ }^{92}$

Interpretive Conditions. Some RUDs set forth the United States's interpretation of vague treaty terms, thereby clarifying the scope of United States consent. For example, Articles 2(1) and 26 of the ICCPR prohibit discrimination not only on the basis of "race, colour, sex, language, religion, political or other opinion, national or social origin, property, [and] birth," but also on the basis of any "other status." ${ }^{, 93}$ The United States attached an understanding stating that this open-ended prohibition on discrimination did not preclude legal distinctions between persons "when such distinctions are, at minimum, rationally related to a legitimate governmental objective." ${ }^{\prime \prime}$ It also attached a reservation to both the ICCPR and the Torture Convention stating that the United States considers itself bound by the prohibitions in those treaties on "cruel, inhuman, or degrading treatment or punishment" only to the extent that such treatment or punishment is prohibited by the U.S. Constitution. ${ }^{95}$ The United

ishment, including such punishment for crimes committed by persons below eighteen years of age" and that "the United States considers itself bound by Article 7 to the extent that 'cruel, inhuman or degrading treatment or punishment' means the cruel and unusual treatment or punishment prohibited by the Fifth, Eighth and/or Fourteenth Amendments to the Constitution of the United States." U.S. RUDs to ICCPR, supra note 86 , paras. I(2)-(3), at $S 4783$.

${ }_{91}$ See U.S. RUDs to Torture Convention, supra note 86, para. I(1), at S17491.

[T] he United States considers itself bound by the obligation under Article 16 to prevent 'cruel, inhuman or degrading treatment or punishment,' only insofar as the term 'cruel, inhuman or degrading treatment or punishment' means the cruel, unusual and inhumane treatment or punishment prohibited by the Fifth, Eighth, and/or Fourteenth Amendments to the Constitution of the United States.

Id.

${ }^{92}$ See U.S. RUDs to Race Convention, supra note 86, para. I(2), at S14326.

To the extent ... that the Convention calls for a broader regulation of private conduct [than is customarily the subject of governmental regulation], the United States does not accept any obligation under this Convention to enact legislation or take other measures under paragraph (1) of Article 2, subparagraphs (1) (c) and (d) of Article 2, Article 3 and Article 5 with respect to private conduct except as mandated by the Constitution and laws of the United States.

Id.

${ }^{93}$ ICCPR, supra note 10, arts. 2(1), 26, 999 U.N.T.S. at 173, 179 (emphasis added).

${ }^{94}$ U.S. RUDs to ICCPR, supra note 86, para. II(1), at S4783.

${ }^{95}$ Id. para. I(3), at S4783; U.S. RUDs to Torture Convention, supra note 86, para. 
States similarly attached understandings to its ratification of the Genocide and Torture Conventions clarifying the circumstances under which conduct will fall within the terms of these treaties. ${ }^{96}$

Non-Self-Execution Declarations. U.S. treatymakers also have included, when ratifying human rights treaties, declarations stating that the substantive provisions of the treaties are not self-executing. ${ }^{97}$ These declarations are designed to preclude the treaties from being enforceable in U.S. courts in the absence of implementing legislation. As the State Department explained in submitting the proposed treaties to President Carter for his transmission to the Senate, "[w]ith such declarations, the substantive provisions of the treaties would not of themselves become effective as domestic law." ${ }^{98}$

The treatymakers have given several reasons for these declarations. First, they believe that, taking into account the substantive reservations and interpretive conditions, U.S. domestic laws and reme-

I(1), at $\$ 17491$. These reservations were in part a response to the European Court of Human Rights's 1989 decision in the Soering case, in which the Court held that a long wait on death row would violate the European Convention on Human Rights's prohibition on "inhuman or degrading treatment or punishment." Soering v. United Kingdom, 161 Eur. Ct. H.R. (ser. A) (1989); see REPORT OF THE COMMTTTEE ON FOREIGN RELATIONS, INTERNATIONAL COVENANT ON CIVIL AND POLITICAL RIGHTS, S. EXEC. REP. 102-23, at 12 (1992) [hereinafter ICCPR REPORT]; David P. Stewart, United States Ratification of the Covenant on Civil and Political Rights: The Significance of the Reservations, Understandings, and Declarations, 42 DEPAUL L. REV. 1183, 1193 (1993).

The understanding attached to the Genocide Convention provides that the requirement in the Convention of an "intent to destroy, in whole or in part, a national, ethnical, racial, or religious group as such" means "the specific intent to destroy, in whole or in substantial part, a national, ethnical, racial or religious group as such." U.S. RUDs to Genocide Convention, supra note 86, para. II(1), at S1377 (emphasis added). The understanding attached to the Torture Convention provides, among other things, that "in order to constitute torture, an act must be specifically intended to inflict severe physical or mental pain or suffering and that mental pain or suffering refers to prolonged mental harm." U.S. RUDs to Torture Convention, supra note 86, para. II(1) (a), at S17491.

:17 A non-self-execution declaration was not attached to the Genocide Convention, but the Senate did include a declaration stating that the President was not to deposit the U.S. instrument of ratification until after Congress had enacted legislation implementing the treaty. U.S. RUDs to Genocide Convention, supra note 86, para. III, at S1378. Senator Hatch (who helped fashion the reservations package to the Genocide Convention) explained that this declaration meant that, in effect, "the Genocide Convention is not to be self-executing." 132 CoNG. REC. S1252-04 (1986). Furthermore, even the implementing legislation for the Convention, which makes genocide a federal criminal offense, states that "[n]othing in this chapter shall be construed as ... creating any substantive or procedural right enforceable by law by any party in any proceeding." 18 U.S.C. $\$ 1092$ (1994).

Message from the President of the United States Transmitting Four Treaties Pertaining to Human Rights, supra note 85, at vi (letter of submittal from Dept. of State, Dec. 17, 1977). 
dies are sufficient to meet U.S. obligations under human rights treaties. $^{99}$ There is thus no additional need, in their view, for domestic implementation. ${ }^{100}$ Second, there is concern that the treaty terms, although similar in substance to U.S. law, are not identical in wording and thus might have a destabilizing effect on domestic rights protections if considered self-executing. ${ }^{101}$ Third, there is disagreement about which treaty terms, if any, would be self-executing. The declaration is intended to provide certainty about this issue in advance of litigation. $^{102}$ Finally, the treatymakers believe that if there is to be a change in the scope of domestic rights protections, it should be done by legislation with the participation of the House of Representatives. ${ }^{103}$

At times, the Executive Branch and the Senate Foreign Relations

${ }^{99}$ For the Senate's views, see INTERNATIONAI CONVENTION ON THE ELIMINATION OF ALI FORMS OF RACIAL DISCRIMINATION, S. EXEC. REP. NO. 103-29, at 6-7 (1994) [hereinafter RACE CONVENTION REPORT]; ICCPR REPORT, supra note 95, at 10; CONVENTION AGAINST TORTURE AND OTHER CRUEL, INHUMAN OR DEGRADING TREATMENT OR PUNISHMENT, S. EXEC. REP. NO. 101-30, at 12 (1990) [hereinafter TORTURE CONVENTION REPORT]; GENOCIDE CONVENTION REPORT, supra note 89, at 15. For a representative administration view, see RACE CONVENTION REPORT, supra, at 33-34.

${ }^{100}$ An important caveat should be noted here with respect to the Torture and Genocide Conventions. For both conventions, the Senate insisted that the President not ratify the treaty until Congress enacted legislation to bring U.S. domestic law into compliance with the treaty. TORTURE CONVENIION REPORT, supra note 99, at 20; GENOCIDE CONVENTION REPORT, supra note 89 , at 26.

${ }^{101}$ For a representative statement, see 1979 Hearings, supra note 80, at 54-55 (State Department memorandum) ("The Covenants and U.S. statutes, while embodying almost identical rights, are not identical in wording. The purpose of the non-selfexecuting declaration, therefore, is to prevent the subjection of fundamental rights to differing and possibly confusing standards of protection in our courts.").

${ }^{102}$ For example, the executive branch maintained that the ICCPR was in its entirety non-self-executing by virtue of both Article 2(2), which provides that "each State... undertakes to take the necessary steps ... to adopt such legislative or other measures as may be necessary to give effect to the rights recognized in this Covenant," and the ICCPR's official annotation, which provides that "the obligation to give effect to the rights recognized in the covenant would be carried out by States through the adoption of legislative or other measures." ICCPR, supra note 10, 999 U.N.T.S. at 17374; see 1979 Hearings, supra note 80, at 315 (memorandum of Roberts Owen, Legal Adviser to the State Department). This view was challenged on the basis of other provisions in the ICCPR. See, e.g., 1979 Hearings, supra note 80, at 276-77 (statement of Oscar Schachter); id. at 287-88 (statement of Louis Henkin).

${ }^{103}$ For example, in defending such a declaration before the ICCPR's Human Rights Committee, the State Department explained that "the decision to make the treaty 'non-self-executing' reflects a strong preference, both within the Administration and in the Senate, not to use the unicameral treaty power of the U.S. Constitution to effect direct changes in the domestic law of the United States." Press Release, Statement by Conrad K. Harper to the Human Rights Committee, USUN Press Release \#49(95), at 3 (Mar. 29, 1995) (on file with the University of Pennsylvania Law Review). 
Committee have stated that the non-self-execution declarations are intended to clarify that the treaties will not create a private cause of action in U.S. courts. ${ }^{104}$ Relying on these statements, Professor David Sloss has argued that, by negative implication, the U.S. treatymakers intended for the human rights treaties to be applied by U.S. courts in situations not requiring the creation of a private cause of action-for example, as a defense to a criminal prosecution or in a civil suit in which some other law provides a right to sue. ${ }^{105}$ This is an unlikely interpretation of the treatymakers' intent. As noted above, the treatymakers have repeatedly expressed concern about the litigation and uncertainty that would result if the human rights treaties applied directly as U.S. law. ${ }^{106}$ Moreover, on a number of occasions, the executive branch and the Senate have expressly stated that the non-selfexecution declarations would preclude all judicial enforcement of the treaties. ${ }^{197}$ In this light, there is little basis for inferring that the

${ }^{1+4}$ See International Convention on the Elimination of All Forms of Racial Discrimination (Ex. C, 95-2): Hearing Before the Comm. of Foreign Relations, U.S. Senate, 103d Cong. 18 (1994) (testimony of State Department Legal Advisor Conrad Harper); Hearings Before the Senate Comm. on Foreign Relations, 102d Cong. 14 (1991) [hereinafter 1991 Hearings]; RACE CONVENTION REPORT, supra note 99, at 25-26 (letter from Acting Secretary of State Strobe Talbott); ICCPR REPORT, supra note 95, at 19.

David Sloss, The Domestication of International Human Rights: Non-Self-Executing Declarations and Human Rights Treaties, 24 YALE J. INT'L L. 129 (1999).

lik: See supra text accompanying notes $84,101-02$.

1"7 As noted above, this was the explanation given in the initial letter of submittal to President Carter, and it was repeated by State Department officials during the 1979 hearings. 1979 Hearings, supra note 80 , at 29 (testimony of Roberts B. Owen, Legal Adviser to the Department of State) (explaining that the non-self-execution declarations "mean that further changes in our laws will be brought about only through the normal legislative process"); id. at 54 (response by the Department of State to a critique of the reservations by the Lawyers Committee on Human Rights) ("A non-self-executing treaty may be applied by our courts only through domestic laws implementing its provisions."). It also was repeated in subsequent letters of submittal, reports from the Senate Foreign Relations Committee, and statements in hearings. See, e.g., 1991 Hearings, supra note 104, at 80 (written answers by Bush administration) (stating that nonself-executing treaties do not "create directly enforceable rights absent implementing legislation"); TORTURE CONVENTION REPORT, supra note 99, at 12 (explaining that the non-self-execution declaration would "clarify that the provisions of the Convention would not of themselves become effective as domestic law"); Marian Nash Leich, Contemporary Practice of the United States Relating to International Law: Human Rights, 82 AM. J. INT'L L. 806, 807 (1988) ("With such a declaration, the provisions of the Convention would not of themselves become effective as domestic law." (citing Memorandum from Secretary of State George P. Shultz (May 10, 1988))); see also GENOCIDE CONVENTION REPORT, supra note 89 , at 26 (explaining that the declaration requiring that the President not deposit the instrument of ratification until after implementing legislation has been enacted "reinforces the fact that the Convention is not self-executing," which means that "no part of the Convention becomes law by itself"). 
treatymakers intended human rights treaties to apply domestically merely because they emphasized that the treaties did not create a private cause of action. Not surprisingly, therefore, courts have construed the non-self-execution declarations as precluding any judicial enforcement of the treaties. ${ }^{108}$

Federalism Understandings. RUDs for human rights treaties typically contain an understanding or other statement relating to federalism. The RUDs attached to the ICCPR, for example, provide that "the United States understands that this Covenant shall be implemented by the Federal Government to the extent that it exercises legislative and judicial jurisdiction over the matters covered therein, and otherwise by the state and local governments." 109 The Bush Administration explained that this understanding "serves to emphasize domestically that there is no intent to alter the constitutional balance of authority between the State and Federal governments or to use the provisions of the Covenant to 'federalize' matters now within the competence of the States. ${ }^{110}$ And the Clinton Administration similarly explained that " $[t]$ here is no disposition to preempt these state and local initiatives or to federalize the entire range of anti-discriminatory actions through the exercise of the constitutional treaty power.... In some areas, it would be inappropriate to do so."111 The federalism understandings, in other words, both highlight and voice respect for the United States's federal structure of government.

ICJ Reservations. U.S. RUDs, like the reservations of many other nations, also typically decline to consent to "ICJ Clauses" in the human rights treaties, pursuant to which claims under the treaties could be brought against the United States in the International Court of Justice. $^{112}$ The United States attached a reservation to its ratification of the Genocide Convention, for example, stating that "before any dispute to which the United States is a party may be submitted to the jurisdiction of the International Court of Justice under [Article IX of the Convention], the specific consent of the United States is required

\footnotetext{
${ }^{108}$ For several such decisions, see supra note 6.

${ }^{109}$ U.S. RUDs to ICCPR, supra note 86, para. II(5), at S8071.

${ }^{110}$ ICCPR REPORT, supra note 95 , at 18.

111 RACE CONVENTION REPORT, supra note 99, at 24.

${ }^{112}$ Like many nations, the United States is not currently a party to the general compulsory jurisdiction of the International Court of Justice. It withdrew its consent to that jurisdiction in 1985, after the court held that it had jurisdiction to adjudicate claims brought by Nicaragua concerning alleged military activities conducted by the United States. BARRY E. CARTER \& PHILIIP R. TRIMBLE, INTERNATIONAL LAW 326 (3d
} ed. 1999). 
in each case." The U.S. treatymakers have explained that the ICJ reservations are designed "to retain the ability of the United States to decline a case which may be brought for frivolous or political reasons." ${ }^{\text {"114 }}$ They also have expressed the view that the reservations will not significantly affect the resolution of disputes under the treaties "because the [ICJ] has not played an important implementation role and because the Convention provides other effective means... for dispute settlement." 115

RUDs are now standard practice for U.S. treatymakers when ratifying human rights treaties. Their validity has been challenged, however, under both international law and U.S. domestic law. We consider the international law objections first.

\section{INTERNATIONAL LAW}

Many scholars have argued that RUDs are inconsistent with the international law that governs treatymaking. In this Part, we explain why these objections are questionable on their own terms. We also explain why the conclusion usually drawn from the objections-that the United States is bound by the human rights treaties as if it had never attached the RUDs-is inconsistent with fundamental international law principles relating to state consent. This Part is addressed primarily to international lawyers and is somewhat technical in nature; generalist readers may wish to skip ahead to Part III, in which we discuss the domestic law objections to the RUDs.

We need to say a word at the outset about the sources of international law relevant to this issue. The Vienna Convention on the Law

"Is U.S. RUDs to Genocide Convention, supra note 86, para. I(1), at S1377; see also U.S. RUDs to Race Convention, supra note 86, para. I(3), at S14326 (stating that "specific consent of the United States is required" before any dispute may be submitted to the jurisdiction of the ICJ); U.S. RUDs to Torture Convention, supra note 86, para. I(2), at $S 17491$ (reserving the right to agree to any procedure for arbitration). The ICCPR does not contain an ICJ Clause.

IIt RACE CONVENTION REPORT, supra note 99, at 8.

${ }^{115}$ Id. There is relatively little controversy regarding the validity of the United States's ICJ reservations. Indeed, the ICJ itself recently gave effect to one of these reservations. In dismissing an action brought by Yugoslavia against the United States for alleged genocide in connection with the Kosovo conflict, the Court noted that "the Genocide Convention does not prohibit reservations" and that "Yugoslavia did not object to the United States reservation." Case Concerning Legality of Use of Force (Yugoslavia v. United States), 1999 I.C.J. 114, I 24 (June 2), available at http://www.icjcij.org/icjwww/idocket/iyus/iyusframe.htm. As a result, the Court concluded that "the said reservation had the effect of excluding [the ICJ Clause] from the provisions of the Convention in force between the Parties." Id. 
of Treaties ${ }^{116}$ is the primary source of the international law objections to RUDs. Unfortunately, the provisions of the Vienna Convention relating to reservations are vaguely worded and have provoked disagreement among commentators and inconsistent national interpretations. ${ }^{117}$ To make matters more uncertain, the United States has not even ratified the Vienna Convention. Many commentators believe that the Convention's terms are nonetheless fully binding on the United States as customary international law, which is the body of international law that "results from a general and consistent practice of states followed by them from a sense of legal obligation." claim is almost certainly too broad, ${ }^{119}$ we will assume for present purposes, as have executive branch officials, that the Convention generally reflects customary international law. ${ }^{120}$

We now turn to the specific international law arguments made against the RUDs. Where examples are needed, we will refer to the RUDs attached to the U.S. ratification of the ICCPR, which have received the most attention and criticism.

${ }^{116}$ Vienna Convention, supra note 22, 1155 U.N.T.S. at 331.

${ }^{117}$ See Catherine J. Redgwell, Reservations to Treaties and Human Rights Committee General Comment No. 24(52), 46 INT'L \& COMP. L.Q. 390 (1997) [hereinafter Redgwell, Reservations]; Catherine Redgwell, Universality or Integrity? Some Reflections on Reservations to General Multilateral Treaties, 64 BRIT. Y.B. INT'L L. 245 (1993) [hereinafter Redgwell, Universality].

118 RESTATEMENT (THIRD) OF THE FOREIGN RELATIONS LAW OF THE UNITED STATES $§ 102(2)$ (1987).

${ }^{119}$ Many provisions of the Vienna Convention, including the articles on reservations, did not reflect customary international law at the time the treaty was drafted. See IAN SINCLAIR, THE VIENNA CONVENTION ON THE LAW OF TREATIES 10-24 (2d ed. 1984). Moreover, the criteria for inferring customary international law binding on the United States from a nonratified treaty like the Vienna Convention are contested. See, e.g., Bruno Simma \& Philip Alston, The Sources of Human Rights Law: Custom, Jus Cogens, and General Principles, 12 AUSTL. Y.B. INT'L L. 82 (1992). Finally, well settled U.S. practice departs from some provisions of the Vienna Convention, most notably its provisions governing treaty interpretation. RESTATEMENT (THIRD) OF THE FOREIGN RELATIONS LAW OF THE UNITED STATES $\$ 325 \mathrm{cmt}$. $\mathrm{g}$ (1987); David J. Bederman, Revixalist Canons and Treaty Interpretation, 41 UCLA L. REv. 953, 972 (1994). As noted below, a customary international law rule does not bind nations that have opted out of the rule during its formative stage. See infra note 124.

${ }^{120}$ The typical executive branch formulation, as reflected in the Government's brief in the Domingues case, is that the Vienna Convention "is generally considered to be consistent with current treaty law and practice as recognized in the United States." Domingues Brief, supra note 13, at 8 n.3; see also RESTATEMENT (THIRD) OF THE FOREIGN RELATIONS LAW OF THE UNITED STATES pt. III, introductory note (1987); Maria Frankowska, The Vienna Convention on the Law of Treaties Before United States Courts, 28 VA.J. INT'L L. 281, 298-99 (1988). 


\section{A. Three Minor Arguments}

We begin with three prevalent, but relatively non-serious, international law arguments. The first is that the RUDs are invalid under Article 27 of the Vienna Convention because they, in effect, limit U.S. treaty obligations to the existing requirements of domestic U.S. law. ${ }^{121}$ Article 27 provides that a nation cannot "invoke the provisions of its internal law as justification for its failure to perform a treaty." language makes clear, Article 27 prohibits reliance on domestic law as an excuse for nonperformance of a treaty obligation. It says nothing about reliance on domestic law as a justification for not consenting to a treaty obligation in the first place. By its terms, then, Article 27 has no bearing on the validity of RUDs, which do not claim any right of nonperformance by the United States with respect to treaty provisions that it has ratified.

The second argument-which concerns the relationship between the RUDs and customary international law-is more complicated, but no more persuasive. This argument consists of two claims: first, that the treaty provisions with respect to which the United States has adopted reservations are already binding on the United States as a matter of customary international law; and, second, that it is not permissible for a nation to agree to a treaty but opt out of provisions that are already binding on that nation under customary international law. Neither claim is sound. As an initial matter, it is unlikely that the provisions of the ICCPR with respect to which the United States has attached reservations reflect binding customary international law. To take what is probably the strongest example invoked by academic critics of RUDs, even if there is sufficient state practice to support a

${ }^{121}$ Riesenfeld \& Abbott, supra note 4, at 627; Schabas, supra note 4, at 278 \& n.35; Weissbrodt supra note 4 , at 57 . A related argument is that no reservations are allowed with respect to the "non-derogable" provisions in the treaties. This argument is a non sequitur. The ICCPR does state that some of its provisions are non-derogable-that is, that these provisions may not be disregarded even in time of emergency. ICCPR, supra note 10 , art. $4(2), 999$ U.N.T.S. at 174 . That statement, however, simply describes the binding effect of the provisions once adopted. There is nothing in the ICCPR, or in the concept of non-derogability, that requires nations to agree to particular treaty provisions in the first place. Cf. ICCPR Human Rights Comm., General Comment 24(52), 52d Sess., 1382d mtg. 1 10, U.N. Doc. CCPR/C/21/Rev.1/Add.6 (1994) [hereinafter General Comment 24(52)] (noting that "there is no automatic correlation between reservations to non-derogable provisions, and reservations which offend against the object and purpose of the Covenant").

122 Vienna Convention, supra note 22, art. 27, 1155 U.N.T.S. at 339 (emphasis added).

${ }^{123}$ See General Comment 24(52), supra note 121, 1 8; Schabas, supra note 4, at 308. 
customary international law ban on executing juvenile offenders, it is likely that the United States has effectively opted out of any such customary international law norm. ${ }^{124}$

More importantly, the argument incorrectly assumes that nations are obligated, when they ratify a treaty, to accept all terms in the treaty that reflect customary international law. There is no basis in international law for such a rule. A nation's attachment of a reservation to a treaty provision is not itself a violation of the provision. It is simply a decision by the nation making the reservation not to bind itself to the treaty regime, and its associated enforcement procedures, with respect to the provision in question. No one claims that nations have an international law obligation to bind themselves to such treaty regimes and procedures in the first instance. It is not argued, for example, that the United States would have violated customary international law if it had declined to ratify the ICCPR altogether. Nor is it argued that the United States is in violation of international law for having declined to ratify the Vienna Convention, even though there is widespread agreement that at least some of its terms reflect customary international law. Since it is clear that nations can refuse to ratify a treaty with terms that are reflective of customary international law, it is difficult to understand how or why international law would obligate them, when they do ratify the treaty, to accept the treaty in its entirety.

Moreover, such a requirement would have undesirable consequences for treatymaking. Given the amorphous nature of customary international law, it will often be difficult for nations to know, when

${ }^{124}$ It is well settled that a nation "that has clearly declared its rejection of a norm or principle of international law while it was in the process of development is not bound by it." HENKIN, supra note 51, at 30; see also RESTATEMENT (THIRD) OF THE FOREIGN RELATIONS LAW OF THE UNITED STATES $§ 102 \mathrm{cmt}$. \& (1987) (explaining that "a state that indicates its dissent from a practice while the law is still in the process of development is not bound by that rule even after it matures"); Ted L. Stein, The Approach of the Different Drummer: The Principle of the Persistent Objector in International Law, 26 HARV. INT'L L.J. 457 (1985) (describing the increasingly important role of persistent objectors in international controversies). The United States-in its RUDs, communications with international organizations (such as the ICCPR's Human Rights Committee and the Inter-American Commission on Human Rights), and other state practices-has clearly declared its rejection of any international law norm outlawing the death penalty for juvenile offenders. See Domingues Brief, supra note 13, at 12-14 (detailing various U.S. objections to such a rule of international law). Numerous commentators have nonetheless argued that the execution of juvenile offenders in the United States violates customary international law. See, e.g., Joan F. Hartman, "Unusual" Punishment: The Domestic Effects of International Norms Restricting the Application of the Death Penalty, 52 U. CIN. L. REv. 655 (1983); Nanda, supra note 4; David Weissbrodt, Execution of Juvenile Offenders by the United States Violates International Human Rights Law, 3 AM. U. J. INT'L L. \& POL'Y 339 (1988). 
they ratify a treaty, whether a particular provision is reflective of customary international law. ${ }^{125}$ A rule that outlawed reservations to all treaty terms reflective of customary international law would thus create substantial uncertainty about the validity of treaty reservations and, more broadly, about the status of treaty relationships.

The third argument is that RUDs are improper because they are an attempt by the United States to ratify the treaties without undertaking any obligations. As Professor Henkin explains, " $[\mathrm{b}] \mathrm{y}$ adhering to human rights conventions subject to these reservations, the United States, it is charged, is pretending to assume international obligations but in fact is undertaking nothing." ${ }^{126}$ It is not clear exactly what the legal claim is here. The claim cannot be that the United States has pledged insufficient "consideration" in entering into these treaty commitments, since it is well settled that, unlike U.S. contract law, the international law governing treaties does not require consideration. ${ }^{127}$ Perhaps the claim is simply that RUDs violate a general duty under international law to act in good faith. There is indeed an international law principle relating to good faith in the treaty context-pacta sunt servanda. That principle, however, simply requires that nations act in good faith in complying with the treaty obligations they have accepted. $^{12 x}$ The pacta sunt servanda principle does not entail any duty by nations to agree to treaty obligations in the first place.

Moreover, whatever its international law basis, the premise of this third argument-that the United States has not assumed any international obligations under the human rights treaties-is false. For some treaties, most notably the Genocide and Torture Conventions, the United States has expressly changed its domestic law in order to com-

1: See Curtis A. Bradley \& Jack L. Goldsmith, Customary International Law as Federal Common Law: A Critique of the Modem Position, 110 HARv. L. REv. 815, 838-41 (1997); Phillip R. Trimble, A Revisionist View of Customary International Law, 33 UCLA L. REv. 665 (1986).

Int" Henkin, supra note 4, at 344; see also, e.g., Bassiouni, supra note 4, at 1179 ("This duality of legal standards places the commitment of the United States to the international rule of law in serious question.").

1:7 See Vienna Convention, supra note 22, art. 2(1)(a), 1155 U.N.T.S. at 333 (defining "treaty" simply as a written "international agreement" governed by international law); Jeffrey L. Dunoff \& Joel P. Trachtman, Economic Analysis of International Law, 24 YALE J. INT'L L. 1, 30 (1999) ("[T] here is no corresponding requirement [under treaty law] for consideration."); Geoffrey R. Watson, The Death of Treaty, 55 OHIo ST. L.J. 781, 797 (1994) ("There has never been a doctrine of consideration in treaty law....").

${ }^{12 \longleftarrow}$ See Vienna Convention, supra note 22, art. 26, 1155 U.N.T.S at 339 ("Every treaty in force is binding upon the parties to it and must be performed by them in good faith." (emphasis added)). 
ply with the treaty obligations. ${ }^{129}$ For other treaties, such as the ICCPR, the United States has maintained that its current human rights protections satisfy its treaty obligations and has committed itself not to retreat from those protections. In doing so, the United States has exposed itself to the argument that its current law does not fully satisfy its treaty obligations, an argument that would not be available if the United States had not made any international commitments. The United States also has committed itself to submit reports detailing its compliance with the treaties, and it has submitted a number of such reports. ${ }^{130}$ Its reports have in turn served as a focal point for arguments concerning U.S. compliance with the treaty obligations. ${ }^{131}$

${ }^{129}$ The United States enacted criminal legislation to implement both the Genocide Convention and the Torture Convention. See 18 U.S.C. $\$ 1091$ (1994) (genocide); 18 U.S.C. $\$ 2340 \mathrm{~A}$ (1994) (torture). In addition, it enacted a broad civil damages remedy for victims of torture to "carry out obligations of the United States under the United Nations Charter and other international agreements pertaining to the protection of human rights." Torture Victim Protection Act of 1991, Pub. L. No. 102-256, 106 Stat. 73 (1992). In 1998, it changed its immigration law to take account of Article 3 of the Torture Convention, which bars the return of a person to another nation "where there are substantial grounds for believing that he would be in danger of being subjected to torture." United States Policy with Respect to Involuntary Return of Persons in Danger of Subjection to Torture, 8 U.S.C. \$ 1231 (Supp. IV 1998). Moreover, the Clinton Administration recently issued an executive order designed to promote executive branch compliance with the various human rights treaties. Exec. Order No. 13,107, 3 C.F.R. 234 (1999).

${ }_{130}$ Of the four major human rights treaties ratified by the United States, three (the ICCPR, the Torture Convention, and the Race Convention) have reporting requirements. The United States has submitted reports to the monitoring bodies associated with each of these three treaties. See United Nations High Commissioner for Human Rights, Treaty Bodies Database, http://www.unhchr.ch/tbs/doc.nsf. Like many nations, the United States has not submitted every report that has been due and has not always submitted its reports on time. As of July 21, 2000, the United States had submitted a total of eleven reports, and five were overdue-a better reporting record than that of many other nations. Id.

${ }^{131}$ For example, these reports have resulted in arguments, by the relevant human rights committees as well as by private groups such as Amnesty International and Human Rights Watch, that aspects of the U.S. death penalty, certain U.S. prison conditions, and U.S. police practices violate treaty obligations. See, e.g., Elizabeth Olson, U.S. Prisoner Restraints Amount to Torture, Geneva Panel Says, N.Y. TIMES, May 18, 2000, at A12 (detailing U.N. objections to the use of electric stun belts and restraint chairs as violations of the international treaty against torture); Amnesty International, Annual Report 2000, http://www.amnesty.org (objecting to the use of the death penalty for minors, police brutality, and ill-treatment in prisons); Human Rights Watch, World Report 2000, http://www.hrw.org/wr2k (citing practices such as police abuse, overincarceration, conditions in custody, and gay- and lesbian-rights violations). 


\section{B. The "Object and Purpose" Argument}

We now turn to the argument that the U.S. reservations to the ICCPR violate the treaty's "object and purpose" and are therefore invalid under Article 19 of the Vienna Convention. ${ }^{132}$ As we explain below, this argument is difficult to evaluate but probably is incorrect. The conclusion usually drawn from the argument is that the United States should be bound by all of the provisions of the ICCPR, including provisions to which the RUDs expressly declined consent. As we explain, there is no basis in international law for this conclusion.

Before proceeding to the analysis, it is worth noting that the ICCPR's Human Rights Committee has embraced both the above premise and conclusion. The Committee has no official power to resolve disputes or issue binding legal interpretations. It is instead charged with receiving reports submitted by nations under the ICCPR's self-reporting provisions and issuing "such general comments as it may consider appropriate." ${ }^{\text {"13 }}$ Nevertheless, it has declared itself to be the definitive interpreter of whether or not a reservation to the ICCPR satisfies the object and purpose test. ${ }^{134}$ And, in two documents, it has directly or indirectly raised questions about the validity of the U.S. RUDs. In 1994, it issued a general comment concerning reservations to the ICCPR, in which it expressed "particular concern" about "widely formulated reservations which essentially render ineffective all Covenant rights which would require any change in national law to ensure compliance with Covenant obligations." ${ }^{\text {135 }}$ It also maintained

${ }^{132}$ See, e.g., Riesenfeld \& Abbott, supra note 4, at 599-603; Schabas, supra note 4, at 285-96; Weissbrodt, supra note 4, at 58. See generally General Comment 24(52), supra note 121 (laying out a framework for assessing reservations to the ICCPR). Article 19 of the Vienna Convention states in relevant part that reservations to a treaty are not allowed if they are "incompatible with the object and purpose of the treaty." Vienna Convention, supra note 22, art. 19, 1155 U.N.T.S. at 337.

1 IS ICCPR, supra note 10, art. 40(4), 999 U.N.T.S at 182. Under Article 41 of the ICCPR, nations may submit declarations agreeing to have the Committee "receive and consider communications to the effect that a State Party claims that another State Party is not fulfilling its obligations under the present Covenant." Id. art. 41(1), 999 U.N.T.S. at 182. In addition, nations that have ratified the First Optional Protocol to the ICCPR have agreed to have the Committee "receive and consider communications from individuals subject to its jurisdiction who claim to be victims of a violation by that State Party of any of the rights set forth in the Covenant." Optional Protocol to the International Covenant on Civil and Political Rights, opened for signature Dec. 19, 1966, art.1, 999 U.N.T.S. 302, 302 (entered into force Mar. 23, 1976). The United States has neither submitted a declaration under Article 41 nor ratified the First Optional Protocol.

1.4 General Comment 24(52), supra note 121, I 18.

Id. I 12. 
in that comment that reservations incompatible with the object and purpose of the ICCPR normally should be treated as severable, meaning that the treaty "will be operative for the reserving party without the benefit of the reservation." 136 Then, in 1995, it issued a comment specifically on U.S. human rights practices, in which it asserted, without analysis, that the U.S. reservations with respect to the death penalty violated the "object and purpose" of the ICCPR ${ }^{137}$ In short, the Human Rights Committee has effectively taken the position that the United States is bound by the ICCPR's death penalty provisions under international law even though it specifically declined to consent to them.

To analyze the Committee's claim, some background is necessary. Nations have made reservations to treaties since the end of the eighteenth century. ${ }^{138}$ International law traditionally imposed strict requirements on when a state could make a reservation and still be a party to a treaty. In a bilateral treaty, a reservation was like a counteroffer; both parties to the treaty had to agree to every reservation before the treaty became valid. For multilateral treaties, the traditional rule was that a reserving state was not a party to a treaty unless every other party to the treaty accepted the reservation. ${ }^{139}$ This traditional unanimity rule was:

based on the concept of the integrity of the terms of a treaty which had been freely negotiated by the prospective parties, and it provided an un-

${ }^{136}$ Id. I 18.

${ }^{197}$ Consideration of Reports Submitted by States Parties Under Article 40 of the Covenant: Comments of the ICCPR Human Rights Committee, 53d Sess., 1413th mtg. I 14, U.N. Doc. CCPR/C/79/Add.50 (1995). Several U.S. officials defended the U.S. RUDs regarding the death penalty in hearings before the Committee held in late March 1995. See ICCPR Human Rights Committee, Summary Record of the 1405th Meeting, 53d Sess., U.N. Doc. CCPR/C/SR.1405 (1995) (Mar. 31, 1995 hearings); ICCPR Human Rights Committee, Summary Record of the 1401st Meeting, 53d Sess., U.N. Doc. CCPR/C/SR.1401 (1995) (Mar. 29, 1995 hearings).

${ }^{138}$ The Senate's reservation to the Jay Treaty in 1794 was the first reservation to a bilateral treaty; Sweden-Norway's reservation to certain parts of the Act of the Congress of Vienna in 1815 was one of the first reservations to a multilateral treaty. William W. Bishop, Jr., Reservations to Treaties, 2 RECUEIL DES COURS 249, 260-62 (1961). Reservations were "sporadic" during the nineteenth century, but then picked up significantly at the dawn of the twentieth century, beginning with the many reservations to the 1899 and 1907 Hague Conventions on the laws of war. FRANK HORN, RESERVATIONS AND INTERPRETIVE DECLARATIONS TO MULTILATERAL TREATIES 7 (1988). For statistics on the use of reservations from 1919 to 1971, see John King Gamble, Jr., Reservations to Multilateral Treaties: A Macroscopic View of State Practice, 74 AM. J. INT'L L. 372, 376-83 (1980).

${ }^{199}$ SINCLAIR, supra note 119, at 54-56; Draft Convention on the Law of Treaties, arts. 14-16, reprinted in 29 AM. J. INT'L L. 657, 659-60 (Supp. 1935). 
ambiguous answer to the question whether a State which had submitted an instrument of ratification or accession, accompanied by a reservation, had become a party to the treaty generally. ${ }^{140}$

With the expansion of multilateral treatymaking after World War II, the unanimity rule came under attack. ${ }^{11}$ There were increasing concerns that the unanimity rule was insufficiently flexible and that it thwarted maximum participation in multilateral treaties, especially human rights treaties. Such flexibility was thought to be essential for the making of human rights treaties among an increasingly large number of countries that were politically and culturally diverse. ${ }^{142}$ The International Court of Justice ("ICJ") embraced a more flexible approach in its 1951 advisory opinion in Reservations to the Convention on the Prevention and Punishment of the Crime of Genocide. ${ }^{143}$ The ICJ reasoned that the aim of securing widespread ratification of the Genocide Convention argued for greater flexibility with regard to reservations. It explained that, with respect to such a treaty, "one cannot speak of individual advantages or disadvantages to States, or of the maintenance of a perfect contractual balance between rights and duties." $^{\text {"44 }}$ The ICJ therefore held that a reserving state could be a party to the Genocide Convention even if some parties to the Convention objected to the reservation. The ICJ stated, however, that if a state makes a reservation incompatible with the object and purpose of the Genocide Convention, the state "cannot be regarded as being a party to the Convention." 145

${ }^{14 y}$ UNTtEd NATIONS CONFERENCE ON THE LAW OF TREATIES: FIRST SESSION, VIENNA, 26 MARCH-24 MAY 1968, at 113, U.N. Doc. A/CONF.39/11, U.N. Sales No. E. 68.v.7 (1969) [hereinafter U.N. CONFERENCE ON THE LAW OF TREATIES] (Testimony of Mr. Sinclair); see also Report of the International Law Commission to the General Assembly, [1951] 2 Y.B. Int'l L. Comm'n 123, 129, U.N. Doc. A/CN.4/SER.A/1951/Add.1 (stating that the unanimity rule is "desirable" for maintaining "uniformity in the obligations of all the parties to a multilateral convention").

${ }^{141}$ Some movement away from the unanimity rule occurred prior to World War II. Most notably, a more flexible approach to conditions was adopted in connection with the Pan American Union of the 1930s. See P.K MENON, AN INTRODUCTION TO THE LAW OF TREATIES 3435 (1992).

${ }^{142}$ For example, the representative at the Vienna Conference from the United Kingdom, a nation that traditionally supported the unanimity rule, acknowledged that the rule "might in modern times be a counsel of perfection, since it had been rendered less practicable by the great expansion of the membership of the international community in recent years." UNITED NATIONS CONFERENCE ON THE LAW OF TREATIES, supra note 140, at 114 .

143 1951 I.C.J. 15. The case came to the court at the request of the United Nations General Assembly.

Iis Id. at 23.

${ }^{145}$ Id. at 29 . 
The Vienna Convention, which was opened for signature in 1969 and entered into force in 1980, embraced a flexible approach to reservations similar to the one outlined in the Genocide Convention decision. ${ }^{146}$ Article 19 of the Convention allows a party to formulate a reservation to a treaty unless "the reservation is incompatible with the object and purpose of the treaty." ${ }^{147}$ Articles 20 and 21 then establish rules for acceptance or rejection of reservations, and the consequences that follow from acceptance or rejection. When a contracting nation accepts another nation's reservation, the reserving nation becomes a party to the treaty in relation to the accepting nation. ${ }^{1+8} \mathrm{~A}$ reservation is deemed accepted by any nation that does not raise an objection to the reservation within twelve months of notification or by the date on which it expressed its consent to be bound by the treaty, whichever is later. ${ }^{149}$ An objection to a reservation does not preclude entry into force of the treaty between the reserving and objecting nation unless the objecting state says so definitively; ${ }^{150}$ rather, the provision to which the reservation relates is simply inapplicable between the two nations to the extent of the reservation. ${ }^{151}$ This flexible approach, as the United Nations's International Law Commission has explained, is designed to encourage widespread participation in treaty regimes. ${ }^{152}$

Neither the Vienna Convention nor the Genocide Convention decision provides much guidance regarding the meaning of the "object and purpose" test. The ICJ stated in the Genocide Convention case that a central purpose of the Genocide Convention is that "as many States

${ }^{146}$ For a detailed historical account of the events between the Genocide Convention case and the final wording of the Vienna Convention, including the initial criticism of the ICJ decision and the eventual acceptance over the subsequent twenty years that a more flexible approach was appropriate, see Redgwell, Universality, supra note 117, at 250-63.

${ }^{147}$ Vienna Convention, supra note 22, art. 19, 1155 U.N.T.S. at 337 . Article 19 also states that reservations are permitted unless the treaty prohibits them or only authorizes reservations other than the ones made. Id.

${ }^{148}$ Id. art. 20(4) (a), 1155 U.N.T.S. at 337.

149 Id. art. 20(5), 1155 U.N.T.S. at 337.

I50 Id. art. 20(4) (b), 1155 U.N.T.S. at 337.

${ }_{151}$ Id. art. 21(3), 1155 U.N.T.S. at 337.

${ }^{152}$ The International Law Commission, in its comments on the draft terms of the Vienna Convention, explained that "a power to formulate reservations must in the nature of things tend to make it easier for some States to execute the act necessary to bind themselves finally to participating in the treaty and therefore tend to promote a greater measure of universality in the application of the treaty." Report of the Commission to the General Assembly, [1966] 2 Y.B. Int'1 L. Comm'n 169, 205, U.N. Doc. A/CN.4/SER.A/1966/Add.1. 
as possible should participate. ${ }^{153}$ This statement, combined with the court's holding, supports a flexible approach to reservations to human rights treaties, but it provides little guidance regarding specific applications of the "object and purpose" test. To make matters more uncertain, there has been no subsequent judicial analysis of the test under either the Vienna Convention or customary international law, and no binding official determination that a reservation has ever violated the test.

Despite these considerations, it seems unlikely that the U.S. RUDs violate the human rights treaties' "object and purpose." We base this conclusion in part on the widespread state practice in support of reservations to human rights treaties. For example, approximately onethird of the parties to the ICCPR made reservations to over a dozen substantive provisions. ${ }^{154}$ Like the United States, many countries conditioned their consent to the treaty in order to conform the treaty obligations to their domestic laws. ${ }^{155}$ France, for example, entered reservations and declarations ensuring that its ICCPR obligations were no more demanding than its domestic law with respect to presidential power, military discipline, immigration, appellate criminal review, regulation of war propaganda, and minority rights. Belgium conditioned its consent to ensure that the ICCPR did not affect its domestic law with respect to sex discrimination in the exercise of royal powers, the protection of juvenile criminal offenders, various criminal procedures, freedom of speech, and marriage. The United Kingdom gave its consent on the condition that its domestic law not be affected with respect to free legal assistance, spousal equality, election law, military

$1: 3$ Reservations to the Convention on the Prevention and Punishment of the Crime of Genocide, 1951 I.C.J. 15, 24. The ICJ continued: "The complete exclusion from the Convention of one or more States would not only restrict the scope of application, but would detract from the authority of the moral and humanitarian principles which are its basis." Id. The Human Rights Committee has described the object and purpose of the ICCPR in a similarly general way. See General Comment 24(52), supra note $121,17$.

The object and purpose of the Covenant is to create legally binding standards for human rights by defining certain civil and political rights and placing them in a framework of obligations which are legally binding for those States which ratify; and to provide an efficacious supervisory machinery for the obliId. gations undertaken.

${ }^{154}$ Redgwell, Reservations, supra note 117, at 393.

25: The information in this paragraph is drawn from the online United Nations Treaty Collection, specifically the Status of Multilateral Treaties Deposited with the Secretary-General, at http://untreaty.un.org/ENGLISH/bible/englishinternetbible/ partI/chapterIV/treaty5.asp [hereinafter Status of Multilateral Treaties]. 
discipline, and immigration. There are many other examples. As one commentator noted, the ICCPR "has... been the object of some sweeping reservations to which few objections have been made."156 Furthermore, other human rights treaties, such as the Convention on the Elimination of Discrimination Against Women and the Convention on the Rights of the Child, are even more "afflicted" by reservations. ${ }^{157}$

This state practice suggests that the United States's reservations to the human rights treaties, which were not substantially different in number or scope from those of other nations, do not violate the object and purpose of the treaties. The selective and specific nature of the U.S. reservations further supports this conclusion. Consider the ICCPR, which protects dozens of rights, none of which is specified to be central to the treaty's purpose. When a treaty protects manifold rights and declines to prohibit reservations, it is difficult to conclude that reservations to a few of the treaty's rights violate its object and purpose. ${ }^{158}$ By contrast, the Genocide and Torture Conventions are both designed to protect a single, overwhelmingly important right. If the United States had ratified those treaties while reserving the right to commit genocide or torture, the reservations might well have violated the treaties' object and purpose, for little would remain of the obligations under the treaty. ${ }^{159}$ This, of course, is not what happened. The United States accepted the prohibitions on genocide and torture and simply attempted, through its RUDs, to clarify the scope of the terms to which it was consenting. ${ }^{160}$

Several technical legal arguments under the Vienna Convention also support the conclusion that U.S. reservations do not violate the object and purpose of the ICCPR. Unlike other human rights treaties, including one of the optional protocols to the ICCPR (which the United States has not ratified), the ICCPR contains no clause excluding reservations and no reference to the object and purpose test. Only 11 of the 146 nations that are parties to the ICCPR have objected to the U.S. RUDs, all on the ground that the reservations violated the

${ }^{156}$ Redgwell, Reservations, supra note 117, at 391.

Id.

${ }^{158}$ Cf. Madeline Morris, Few Reservations About Reservations, I CHI. J. INT'L L. 341, $343(2000)$ ("There is a difference between frustrating the purposes of a treaty and fulfilling some, but not all, of its purposes.").

159 See ANTHONY Aust, MODERN TREATY LAW AND PRACTICE 110-11 (2000).

${ }^{160}$ See supra text accompanying notes 95-96. 
object and purpose of the treaty. ${ }^{161}$ None of these objections came "within the twelve months of communication of the U.S. reservations." ${ }^{162}$ Under the terms of the Vienna Convention, therefore, the U.S. reservations are deemed accepted. ${ }^{163}$ In addition, none of the nations that objected to the reservations claimed that the United States was not a party to the treaty. Under the Vienna Convention, then, the United States is, at worst, a party to the treaty and the provisions to which the reservations relate do not apply between the United States and the objecting nations. ${ }^{164}$

Some commentators have responded to these latter points by arguing that other nations do not have the power under international law to consent to reservations that violate the object and purpose of a treaty. The Genocide Convention decision does offer some support for this argument. The Vienna Convention, which supersedes the statement of customary international law in the Genocide Convention decision, is unclear about whether the rules for acceptance of reservations in Article 20 apply to all reservations, or only to ones that survive Article 19 's object and purpose test. ${ }^{165}$ Both the Vienna Convention's

Iil Status of Multilateral Treaties, supra note 155. Twelve of the 132 countries that are parties to the Genocide Convention have objected to the U.S. RUDs, 3 of the 119 countries that are parties to the Torture Convention have objected to the U.S. RUDs, and none of the 156 countries that are parties to the Race Convention has objected to the U.S. RUDs. Id. Compare those numbers with the test set forth in the Race Convention, whereby a reservation will be deemed "incompatible" with the object and purpose of the Convention if two-thirds of the parties object to the reservation. International Convention on the Elimination of All Forms of Racial Discrimination, U.N. GAOR 3d Comm., 20th Sess., Annex, Agenda Item 58, art. 20(2), U.N. Doc. A/RES/2106 (1966), reprinted in 5 I.L.M. 350, 365 (1966). There have been no specific objections to the United States's non-self-execution declarations in connection with any of the treaties. Status of Multilateral Treaties, supra note 155.

1". Redgwell, Reservations, supra note 117, at 395.

${ }^{163}$ See Vienna Convention, supra note 22, art. 20(5), 1155 U.N.T.S. at 337. ("[U]nless the treaty otherwise provides, a reservation is considered to have been accepted by a State if it shall have raised no objection to the reservation by the end of a period of twelve months after it was notified of the reservation or by the date on which it expressed its consent to be bound by the treaty, whichever is later.").

${ }^{\text {it }}$ See Vienna Convention, supra note 22, art. 20(4)(b), 1155 U.N.T.S. at 337 ("[A]n objection by another contracting State to a reservation does not preclude the entry into force of the treaty as between the objecting and reserving States unless a contrary intention is definitely expressed by the objecting State."); id. art. 21(3), 1155 U.N.T.S. at 337 ("When a State objecting to a reservation has not opposed the entry into force of the treaty between itself and the reserving State, the provisions to which the reservation relates do not apply as between the two States to the extent of the reservation.").

Ji: For the International Law Commission's commentary on the original draft version of Articles 19 and 20, suggesting that the object and purpose test is not an inde- 
drafting history and the state practice under the Convention suggest that Article 20 applies to all reservations, and thus that the object and purpose test is not an independent bar to other nations' acceptance of reservations under the Vienna Convention. ${ }^{166}$ The Human Rights Committee appears to agree with this reading of the Convention because, in explaining why the failure by nations to object to reservations to the ICCPR did not constitute an acceptance of the reservations, it felt compelled to maintain that the Vienna Convention's rules about tacit consent to reservations "are inappropriate to address the problem of reservations to human rights treaties." 167 These factors, taken together, suggest that the best reading of the Vienna Convention and related customary international law is that other nations have effectively consented to the validity of the U.S. reservations to the ICCPR. $^{168}$

Because of ambiguities in the Vienna Convention, and the lack of a centralized decisionmaker with authority to determine the validity of reservations, there is room for disagreement with this conclusion concerning tacit acceptance. ${ }^{169}$ This fact is probably beside the point because, as discussed above, the U.S. reservations almost certainly do not violate the ICCPR's object and purpose. But even if one concluded that the United States's RUDs did violate the object and purpose test and that the violations were not cured by other nations' failure to object to them, it is clearly incorrect to conclude, as the ICCPR's Human Rights Committee and others have, that the United States continues to be bound by the ICCPR, including ICCPR terms to which it did not consent. $^{170}$ One of the most established principles in international law is

pendent barrier to reservation acceptance by other nations, see U.N. CONFERENCE ON THE LAW OF TREATIES, supra note 140 . In subsequent negotiations, many nations proposed amendments to the Vienna Convention to clarify that the object and purpose test was an absolute bar to reservations, but these amendments were all rejected. See Redgwell, Universality, supra note 117, at 257-60.

${ }^{166}$ On the drafting history of the Vienna Convention and state practice concerning reservations, see Redgwell, Universality, supra note 117, at 273-78.

${ }^{167}$ General Comment 24(52), supra note 121, 117.

${ }^{168}$ At the very least, the drafting history of the Vienna Convention, as well as subsequent state practice, suggest that as a matter of customary international law arising from the Vienna Convention, the object and purpose test is not a bar to reservations independent of a nation's consent to the reservations.

${ }^{169}$ This issue is more complex than our already complicated discussion suggests. For an overview of the debate regarding the legal effect of reservations that are incompatible with the object and purpose of a treaty, see AUST, supra note 159, at 105-30; Redgwell, Universality, supra note 117, at 263-69.

${ }^{170}$ See General Comment 24(52), supra note 121, I 18 (concluding that a reservation that violates the object and purpose test "will generally be severable, in the sense that the Covenant will be operative for the [United States] without benefit of the res- 
that "in treaty relations a state cannot be bound without its consent."171 It would contravene this fundamental principle of international law to invalidate a reservation to a treaty but hold the party to the remainder of the treaty without recognizing the reservation. ${ }^{172}$ This conclusion is especially clear where, as with the U.S. ratification of the ICCPR, the reservations are "integral parts of its consent to be bound." ${ }^{173}$ The United Nations's International Law Commission recently confirmed this conclusion and (along with several individual nations) expressly rejected the contrary views of the ICCPR's Human Rights Committee. ${ }^{174}$

At first glance, it might appear that two decisions from the European Court of Human Rights support the Committee's views. In these decisions, the European Court held that reservations to the European Convention on Human Rights were invalid, and it enforced the entire

ervation").

${ }^{171}$ See Reservations to the Convention on the Prevention and Punishment of the Crime of Genocide, 1951 I.C.J. 15, 21 (Mfay 28); see also, e.g., RESTATEMENT (THIRD) OF THE FOREIGN RELATIONS LAW OF THE UNITED STATES pt. I, introductory note at 18 (1987) ("Modern international law is rooted in acceptance by states which constitute the system."); Vienna Convention, supra note 22, art. 34, 1155 U.N.T.S. at 341 ("A treaty does not create either obligations or rights for a third State without its consent."); Louis HeNkIN, INTERNATIONAL Law: POlITICS AND VALUES 28 (1995) ("For treaties, consent is essential. No treaty, old or new, whatever its character or subject, is binding on a state unless it has consented to it.").

${ }^{172}$ See Redgwell, Universalit), supra note 117, at 267 ("It was never the intention of the ICJ, the ILC or the [Vienna Convention] that a State should be bound by a provision to which it had not indicated its consent.").

${ }_{173}$ Observations by the United States on General Comment 24, 3 INT'L HUM. RTS. REP. 265,269 (1996) [hereinafter U.S. Response]; $c f$. Certain Norwegian Loans (Fr. v. Nor.), 1957 I.C.J. 9, 66 (July 6) (separate opinion of Judge Lauterpacht) (arguing that when an invalid reservation is an essential component of a nation's consent to the compulsory jurisdiction of the International Court of Justice, that nation's entire consent is "devoid of legal effect").

${ }_{171}$ The United States, Great Britain, and France strongly objected to the views of the ICCPR's Human Rights Committee expressed in General Comment 24(52), including its views concerning the proper remedy for invalid reservations. Observations by France on General Comment 24 on Reservations to the ICCPR, 4 INT'L HUM. RTS. REP. 6, 6-8 (1997); Observations by the United Kingdom on General Comment 24, 3 INT'L HUM. RTS. REP. 261, 261-69 (1996); U.S. Response, supra note 173, at 265-69. In a 1997 report, the United Nations's International Law Commission similarly rejected a number of the conclusions in General Comment 24(52). Report of the International Law Commission on the Work of its Forty-Ninth Session, U.N. GAOR, 52d Sess., Supp. No. 10, U.N. Doc. A/52/10 (1997). The tension between General Comment 24(52) and the requirement of state consent was exacerbated recently when the Human Rights Committee concluded that parties to the ICCPR do not have the right to withdraw from that treaty. General Comment 26, U.N. GAOR, Hum. Rts. Comm., 53d Sess., Supp. No. 40, I 5, U.N. Dac. A/53/40 (1998). 
treaty, including the terms to which reservations were taken. ${ }^{175}$ These decisions, however, have little relevance to the U.S. reservations to the ICCPR and other global human rights treaties. In part, this is because the decisions were premised on a finding that the countries intended to be bound by the European Convention regardless of the fate of their reservations. ${ }^{176}$ By contrast, the U.S. RUDs were clearly a condition of U.S. ratification. ${ }^{177}$ More significantly, the European Court was "not simply applying general principles of treaty law." interpreting the particular provisions of the European Convention in light of the Convention's role as a "constitutional instrument of European public order (ordre public)."179 These principles do not apply beyond Europe and thus cannot supersede the controlling principles of the Vienna Convention and related customary international law.

In sum, if the U.S. RUDs really do violate the object and purpose of the human rights treaties, and the acquiescence of the other parties to the treaties has not rectified this problem, there are only two possible remedies under international law: either the United States is not a party to the treaty provisions with respect to which it has reserved (which yields the same result as if the RUDs were enforced), or the United States is not a party to the treaty at all. ${ }^{180}$ Human rights advocates have argued against the former possibility but they have not, of

${ }^{175}$ See Loizidou v. Turkey, 310 Eur. Ct. H.R. (ser. A) (1995); Belilos v. Switzerland, 132 Eur. Ct. H.R. (ser. A) (1987).

${ }^{176}$ In the Belilos case, Switzerland explicitly conceded this point. 132 Eur. C.. H.R. at 28; Council of Europe, European Court of Human Rights, Doc. Cour/Misc (87) 237,45 (transcript of public hearing, Oct. 26, 1987). See generally Schabas, supra note 4, at 319 . In the Loizidou case, by contrast, the court inferred this intent. 310 Eur. Ct. H.R. at 28; see Schabas, supra note 4, at 321; see also Elena A. Baylis, General Comment 24: Confronting the Problem of Reservations to Human Rights Treaties, 17 BERKELEX J. INI'L L. 277, 302-06 (1999).

177 See supra Part I.B and text accompanying note 86.

${ }^{178}$ Redgwell, Universality, supra note 117, at 266; see also Susan Marks, Reservations Unhinged: The Belilos Case Before the European Court of Human Rights, 39 INT'L \& COMP. L.Q. 300, 327 (1990) (analyzing the Belilos decision and tying it to "structural features of the [European] Convention").

179 Loizidou, 310 Eur. Ct. H.R. at 27.

${ }^{180}$ By analogy, these are the two possibilities generally available under U.S. law with respect to the severability of statutory provisions. If a court finds a portion of a statute to be invalid, it will generally try to sever the invalid portion and enforce the remainder. However, if it determines that the statute would not have been enacted in the absence of the invalid portion, it will decline to enforce the statute as a whole. See, e.g., Regan v. Time, Inc., 468 U.S. 641, 652-55 (1984) (plurality opinion); Champlin Ref. Co. v. Corp. Comm'n of Okla., 286 U.S. 210, 234 (1932). See generally John Copeland Nagle, Severability, 72 N.C. L. REv. 203 (1993) (tracing the development of judicial tests for determining when a statute should be found severable). 
course, argued in favor of the latter.

$* \quad *$

In the early stages of the international human rights movement, flexibility regarding reservations was viewed as necessary to achieve widespread ratification of human rights treaties. Now that this goal has been achieved, human rights advocates have changed their position, attacking the RUDs on the ground that the flexible approach to reservations adopted in the Vienna Convention is "inappropriate" for human rights treaties. Even more dramatically, it is claimed that nations can be bound by the very treaty terms to which they declined to consent. This change of position by the human rights community may reflect an understandable effort to strengthen international human rights law, but it is inconsistent with settled principles of international law. ${ }^{181}$

\section{DOMESTIC CONSTITUTIONAL LAW}

In the last Part, we explained why the U.S. RUDs are consistent with customary international law principles of treaty formation. Even if the international law objections to the RUDs were more persuasive, however, they would not provide a basis for invalidating the RUDs in U.S. courts. In a variety of circumstances, U.S. courts give effect to actions by political branch actors even if those actions violate international law. For example, they apply a federal statute even if it violates customary international law ${ }^{182}$ and even if it conflicts with an earlier inconsistent treaty. ${ }^{183}$ Similarly, they uphold executive branch actions that violate customary international law. ${ }^{184}$ In these and many other

1*I In Part IV below, we discuss how the change of position may also have undesirable policy consequences for the development of international human rights law.

${ }_{1 \times 2}$ See, e.g., Galo-Garcia v. INS, 86 F.3d 916, 918 (9th Cir. 1996); United States v. Yunis, 924 F.2d 1086, 1090-91 (D.C. Cir. 1991); Garcia-Mir v. Meese, 788 F.2d 1446, 1453-54 (11 th Cir. 1986).

${ }^{1 \times 3}$ See, e.g., Breard v. Greene, 523 U.S. 371, 376 (1998) (per curiam); Chae Chan Ping v. United States (The Chinese Exclusion Case), 130 U.S. 581, 600 (1889); Whitney v. Robertson, 124 U.S. 190, 194 (1888); Edye v. Robertson (The Head Money Cases), 112 U.S. $580,597-99$ (1884).

${ }^{144}$ See, e.g., Barrera-Echavarria v. Rison, 44 F.3d 1441, 1451 (9th Cir. 1995); Gisbert v. Attorney Gen., 988 F.2d 1437, 1447-48 (5th Cir. 1993); Garcia-Mir, 788 F.2d at 1454. But see Fernandez v. Wilkinson, 505 F. Supp. 787 (D. Kan. 1980), affd on other grounds sub nom. Radriguez-Fernandez v. Wilkinson, 654 F.2d 1382 (10th Cir. 1981). The relationship between treaties and the executive branch is less clear. It is possible that courts will apply self-executing treaties to restrict executive branch action in some cir- 
contexts, U.S. courts follow a dualist approach to the relationship between international law and domestic law: They treat international and domestic law as distinct, they rely on domestic law to determine international law's status within the U.S. legal system, and, in case of a conflict, they generally give domestic law primacy over international law. ${ }^{185}$

Consistent with this dualistic approach, U.S. courts are likely to judge the legal validity of the RUDs ultimately by reference to domestic constitutional law. In recognition of this point, critics have argued that the RUDs are inconsistent with constitutional principles relating to separation of powers, the Supremacy Clause, the treaty power, and federalism. In this Part, we explain why these constitutional arguments are unpersuasive. We begin, however, with some general observations concerning the nature of judicial review in the context of the RUDs.

\section{A. Judicial Review}

Critics of the RUDs argue for extraordinary judicial intervention into the treaty process. Consider the Domingues case, in which the petitioner argued that Nevada's death penalty for juvenile offenders violated Article 6 of the ICCPR. ${ }^{186}$ For the petitioner to prevail, a U.S. court would have had to invalidate the treatymakers' reservation to Article 6; determine that the United States was nonetheless still bound by the entire treaty, including the provision to which it declined consent; disregard the non-self-executing declaration; and hold that the entire treaty, including the provision to which the United States did not consent, thereby applied to preempt Nevada law. To state these claims is to understand why courts are not likely to engage in the aggressive forms of judicial review needed to credit them.

U.S. courts have never exercised judicial review to invalidate either the domestic or international effects of a treaty on structural constitutional grounds. In part, this is because the text of the Constitu-

cumstances. Cf. United States v. Alvarez-Machain, 504 U.S. 655, 667 (1992) (assuming that executive branch violation of a self-executing extradition treaty would provide a basis for dismissing a criminal prosecution). The validity of the President's termination of a treaty, however, may be nonjusticiable. Goldwater v. Carter, 444 U.S. 996, 1002-03 (1979) (plurality opinion).

${ }^{185}$ See generally Curtis A. Bradley, Breard, Our Dualist Constitution, and the Internationalist Conception, 51 STAN. L. REV. 529, 530-31 (1999) (explaining differences between "monist" and "dualist" approaches to the relationship between international and domestic law).

${ }^{186}$ See supra text accompanying notes 7-13. 
tion is relatively silent about the treatymaking process. As Hayden notes, the Treaty Clause's "elasticity in details" left "to successive Senates and to successive Presidents the problem and the privilege of determining under the stress of actual government the precise manner in which they were to make the treaties of the nation." ${ }^{\text {"187 }}$ U.S. courts also have recognized that, although treaties are legal instruments, their creation and especially their enforcement are heavily informed by political factors. ${ }^{188}$ These attributes of the treaty power, taken together, have resulted in numerous practical and sometimes changing accommodations among the treatymakers (some of which have provoked disagreement) about how treaties are made, enforced, and terminated. Examples include the particular procedures for making treaties, ${ }^{1 \times 9}$ the rise of congressional-executive agreements as a substitute (or near-substitute) for treaties, ${ }^{190}$ and the power to terminate treaties, ${ }^{191}$ none of which is addressed by constitutional text, and all of which have developed in particular ways as a result of the contingencies of domestic and international politics.

Recognizing the lack of textual guidance and the importance of political contingency in this context, U.S. courts have taken a largely passive role in the institutional developments concerning the making and enforcement of treaties. They usually defer to the accommodations of the political branches (such as with the rise of congressionalexecutive agreements) ${ }^{192}$ or abstain from adjudicating disputes between the political branches (such as over the termination of treaties). ${ }^{193}$ Similarly, they consider many matters pertaining to the nego-

inz HAIDEN, supra note 26, at 2.

I×x See, e.g., The Head Money Cases, 112 U.S. at 598 ("A treaty is primarily a compact between independent nations. It depends for the enforcement of its provisions on the interest and the honor of the governments which are parties to it.").

in't HENKIN, supra note 24, at 177-78.

${ }^{\prime * *}$ See RESTATEMENT (THIRD) OF THE FOREIGN RELATIONS LAW OF THE UNITED STATES $\$ 303 \mathrm{cmt}$. e (1987) ("The prevailing view is that the Congressional-Executive agreement can be used as an alternative to the treaty method in every instance."); HENKIN, supra note 24, at 217 ("[I]t is now widely accepted that the CongressionalExecutive agreement is available for wide use, even general use, and is a complete alternative to a treaty ...." (citations omitted)).

"'li HENKIN, supra note 24, at 211-14.

I". See generally Made in the USA Found. v. United States, 56 F. Supp. 2d 1226 (N.D. Ala. 1999) (rejecting a constitutional challenge to the North American Free Trade Agreement); Bruce Ackerman \& David Golove, Is NAFTA Constitutional?, 108 HARV. L. REv. 799 (1995) (evaluating the constitutionality of international accords reached as congressional-executive agreements).

See Goldwater v. Carter, 444 U.S. 996, 1002 (1979) (plurality opinion) (expressing the view of four Justices that the President's constitutional authority to terminate a 
tiation, observance, and status of treaties to be "political questions" committed to the discretion of the political branches. ${ }^{194}$ They also give "great weight" to the executive branch's interpretation of a treaty. ${ }^{195}$ And, of course, judicial deference to political branch arrangements is especially strong in situations, as with the RUDs, in which the political branches all agree on the assertion of constitutional power. ${ }^{196}$

With these points in mind, we now turn to the specific constitutional arguments made by critics of the RUDs.

\section{B. Separation of Powers}

Some commentators have suggested that the RUDs violate separation of powers principles. ${ }^{197}$ There are several related claims here. One is that the RUDs may infringe on the President's constitutional prerogatives in making treaties. Another is that RUDs are "antimajoritarian" because they allow a minority of senators to force limitations on treaties through their power to block the two-thirds advice and consent needed for ratification. ${ }^{198}$ Yet another is that the RUDs constitute an improper "line-item veto" because the Senate is in effect trying to change the terms of the treaty. ${ }^{199}$ Finally, some commentators have claimed that the RUDs improperly interfere with the role of the judicial branch in interpreting treaties.

treaty is a nonjusticiable political question).

${ }^{194}$ Edwin D. Dickinson, Editorial Comment, International Political Questions in the National Courts, 19 AM. J. INT'L L. 157, $161 \&$ n.17 (1925) (citing cases and examples).

${ }^{195}$ United States v. Stuart, 489 U.S. 353, 369 (1989); Sumitomo Shoji America, Inc. v. Avagliano, 457 U.S. 176, 184-85 (1982); Kolovrat v. Oregon, 366 U.S. 187, 194 (1961); see also RESTATEMENT (THIRD) OF THE FOREIGN RELATIONS LAW OF THE UNITED STATES \$ 326(2) (1987); Curtis A. Bradley, Chevron Deference and Foreign Affairs, 86 VA. L. REV. 649, 701-07 (2000).

${ }^{196}$ See Dames \& Moore v. Regan, 453 U.S. 654, 668 (1981). The opinion notes: When the President acts pursuant to an express or implied authorization from Congress, he exercises not only his powers but also those delegated by Congress. In such a case the executive action "would be supported by the strongest of presumptions and the widest latitude of judicial interpretation, and the burden of persuasion would rest heavily upon any who might attack it."

Id. (quoting Youngstown Sheet \&: Tube Co. v. Sawyer, 343 U.S. 579, 637 (1952) (Jackson, J., concurring)); cf. HAYNES, supra note 21, at 608 ("No President has ever taken the ground that the Senate's right to amend treaties is not included in the power to reject or to ratify.").

${ }_{197}$ See, e.g., Damrosch, supra note 4; Riesenfeld \& Abbott, supra note 4.

${ }_{198}$ Riesenfeld \& Abbott, supra note 4, at 600-01.

199 John Quigley, The Rule of Non-Inquiry and Human Rights Treaties, 45 CATH. U. L. REv. 1213, 1233-34 (1996). This argument was also made in the Domingues case, discussed above. See supra text accompanying notes 7-13. 
Separation of powers claims are often difficult to assess because there is no settled understanding of the proper relationship among the three branches of the federal government. Regardless of whether one views these matters from a formalist or functionalist perspective, ${ }^{200}$ however, the various arguments made against RUDs under the rubric of separation of powers are unconvincing. This is especially true, we hope to show, when one descends from abstract concerns about democracy and executive power, and attends to the concrete terms and structure of the Constitution.

Most of the separation of powers claims against the RUDs relate to the separation between the legislative and executive branches. There are three fundamental problems with these claims. First, the factual supposition underlying the claims-that the Senate "imposes" the RUDs on an otherwise unwilling President-is simply false. As discussed above, RUDs to human rights treaties all have been proposed by presidents in the first instance rather than by the Senate, and they are often adopted by the Senate without change. The Senate sometimes revises proposed presidential RUDs, but always in cooperation with the Executive Branch, always in a modest way, and sometimes in the direction of narrowing the scope of the RUDs. ${ }^{201}$ Even if RUDs could, in theory, constitute interference with presidential power, a point that we contest below, interference is not an issue in the area of human rights RUDs, where the President and Senate have worked together.

Second, even if the Senate attached RUDs unilaterally, the RUDs would not in any way bind the President. The Senate is required to attach the RUDs before, and not after, ratification, ${ }^{202}$ and the Presi-

$2^{2 * 1}$ For a description of these perspectives, see Rebecca L. Brown, Separated Powers and Ordered Liberty, 139 U. PA. L. REv. 1513, 1522-31 (1991); Thomas W. Merrill, The Constitutional Principle of Separation of Powers, 1991 SUP. CT. REv. 225, 227; Peter L. Strauss, Formal and Functional Approaches to Separation-of-Powers Questions-A Foolish Inconsistency?, 72 CORNELL L. REV. 488, 489 (1987).

$2 " 11$ For example, when the Senate Foreign Relations Committee ultimately endorsed the Torture Convention, it noted that the RUDs were "the product of a cooperative and successful negotiating process between the executive branch, this committee, and interested private groups." REPORT OF THE COMM. ON FOREIGN RELATIONS, CONTENTION AGAINST TORTURE AND OTHER CRUEL, INHUMAN OR DEGRADING TREATMIENT OR PUNISHMENT, S. EXEC. REP. NO. 101-30, at 4 (1990). Of course, this cooperation takes place against the background of the Senate's potential threat of nonconsent, a point that we discuss below.

"2"2 See Fourteen Diamond Rings v. United States, 183 U.S. 176, 180 (1901) ("The meaning of the treaty cannot be controlled by subsequent explanations of some of those who may have voted to ratify it."); $i d$. at 183 (Brown, J., concurring) ("The Senate has no right to ratify the treaty and introduce new terms into it, which shall be obliga- 
dent is never obligated to accept the RUDs. If he disagrees with them, he can simply refuse to ratify the treaty, as several presidents have in fact done (outside of the human rights context). ${ }^{203}$ This distinguishes RUDs from a true line-item veto, in which one branch, the Executive, is attempting to bind another branch, Congress, to some parts of the legislation while vetoing other parts. It also distinguishes them from the line-item veto and one-house veto provisions that have been held invalid by the Supreme Court. The Court held those veto provisions to be invalid because they constituted attempts by one branch or house of the legislature to alter already-enacted law. ${ }^{204}$ RUDs do not alter already-enacted law. Rather, they are analogous to a bill passed by both Houses of Congress and sent to the President for his approval or veto. The last constitutional actor in the process-the Presidentretains the discretion to sign the bill despite disagreement with its content, or to veto the bill because of disagreement with its content. The President plays a functionally identical role with respect to Senate conditions. In neither case does he have sole discretion to make federal law, but in both cases he has the final say about whether federal law is made. ${ }^{205}$

Third, RUDs attached by the Senate are not "undemocratic" or "antimajoritarian" in a constitutionally meaningful sense. It is true that a minority of senators can insist on a package of RUDs as a precondition of senatorial consent to the treaty. But this power flows from Article II, which requires two-thirds senatorial consent as a precondition to making treaty commitments. In other words, the minority power of conditional consent is a direct consequence of the Constitution's particular super-majoritarian treatymaking procedure. This is but one of many devices in the Constitution designed to protect mi-

tory upon the other power ...."); N.Y. Indians v. United States, 170 U.S. 1, 23 (1898) (refusing to give effect to a treaty proviso adopted by the Senate because "there is no evidence that it ever received the sanction or approval of the President").

${ }^{203}$ For example, President Taft declined to ratify arbitration treaties with France and Great Britain after the Senate insisted on certain reservations. RESTATEMENT (THIRD) OF THE FOREIGN RELATIONS LAW OF THE UNITED STATES $\$ 303$ reporters' note 3 (1987).

${ }^{204}$ See Clinton v. New York, 524 U.S. 417, 447 (1998) (invalidating Line Item Veto Act because, unlike other statutes, "this Act gives the President the unilateral power to change the text of duly enacted statutes"); INS v. Chadha, 462 U.S. 919, 952, 956 (1983) (invalidating one-House veto because "the House took action that had the purpose and effect of altering the legal rights, duties, and relations of persons").

${ }^{205}$ Except, of course, that the Senate cannot override the President's refusal to ratify in the treaty context. In this regard the Senate has less authority vis-à-vis the President in the treatymaking process than the House and Senate have vis-à-vis the President in the domestic lawmaking process. 
nority interests. ${ }^{2010}$

One might argue that the original reasons for the Senate's minority veto-to create a structural bias against international agreements and to protect state prerogatives ${ }^{207}$-are no longer valid. This is not a view that we, or any branch of the federal government, share. In any event, this argument has little purchase in the context of RUDs attached to human rights treaties. In this context, Congress and the President remain free to enact a subsequent statute that contains domestic human rights protections without the limitations contained in the RUDs. ${ }^{2(13}$ This later-enacted statute, which a minority of senators would have no power to block, ${ }^{209}$ would, as a matter of U.S. domestic law, supersede any prior inconsistent provisions of the treaty. ${ }^{210}$

Finally, there is no merit to the claim that the RUDs infringe on the constitutional role of the judiciary. It is true that the RUDs are designed in part to affect the judiciary's interpretation and application of the treaties in question. It is well settled, however, that the political branches, by virtue of their lawmaking powers, have significant influence over the judiciary's interpretation and application of nonconstitutional law. Thus, for example, Congress often defines the terms in its statutes, and there is no question that these definitions constitute part of the law that is to be applied by the courts. More broadly, Congress influences the scope of judicial interpretation by controlling the content and form of federal law. The RUDs are similarly part of the law created by the treatymakers, and they are therefore binding on courts in their interpretation and application of the treaties. Unlike mere "legislative history," the relevance of which is controversial in the statutory interpretation context, the RUDs are subjected to all of the procedural requirements specified in the Constitution. Nor are RUDs after-the-fact efforts by the Senate or President to control judicial interpretation of the treaty, since they are formulated prior to ratification, approved by both the Senate and

21 ins Other constitutional provisions designed to protect minority interests include the Article I bicameralism and presentment process, the Article II impeachment process, the Article V constitutional amendment process, and, of course, the Bill of Rights.

${ }^{217}$ See Arthur Bestor, Respective Roles of Senate and President in the Making and Alrogation of Treaties-The Original Intent of the Framers of the Constitution Historically Examined, 55 WASH. L. REV. 1, 33-39 (1979); Rakove, supra note 26, at 236-39.

2"1y Of course, this legislation, like the treaty that it would supersede, must be consistent with the Constitution.

'A A minority of senators might have some ability to block such a statute through the filibuster power, just as they would have the power to block any other statute.

${ }^{210}$ See supra note 3 and accompanying text. 
President, and made part of the U.S. ratification documents. ${ }^{211}$

\section{Non-Self-Execution}

Many of the constitutional arguments against the RUDs have been directed at the non-self-execution declarations. These arguments boil down to two claims: first, that the declarations violate the terms of the Supremacy Clause; and, second, that they exceed implicit limits on the scope of the treaty power.

\section{The Supremacy Clause}

The Supremacy Clause states in relevant part that "all Treaties made, or which shall be made, under the Authority of the United States, shall be the supreme Law of the Land; and the Judges in every State shall be bound thereby." ${ }^{212}$ Some commentators have argued that this language mandates that human rights treaties have the status of self-executing federal law, regardless of the wishes of the U.S. treatymakers. ${ }^{213}$ As Professor Henkin states, "treaties are declared to be the supreme law of the land .... [I]t should not require legislative implementation to convert [a treaty] into United States law." ${ }^{\text {"214 }}$ Henkin concludes that the "pattern of non-self-executing declarations [attached to human rights treaties] threatens to subvert the constitutional treaty system.",215

Although the word "shall" in the Supremacy Clause gives this argument surface plausibility, the argument becomes doubtful once one considers the purposes of the Supremacy Clause and its well-settled application outside the RUDs context. By its terms, the Clause obviously does make federal laws supreme over state laws. The Clause does not, however, purport to affect the power of U.S. lawmakers to define the domestic scope of the law they make, either as to the states or as to other federal laws. In other words, the Clause does not, as RUDs critics would have it, operate as a limit on federal lawmaking power.

${ }^{211}$ There has been substantial debate, especially in the context of arms control treaties, over whether presidents have the power to "reinterpret" treaties after ratification. For examples of some of the positions in this debate, see Symposium, Arms Control Treaty Reinterpretation, 137 U. PA. L. REV. 1351 (1989). The RUDs to the human rights treaties do not implicate this debate.

${ }_{212}^{212}$ U.S. CONST. art. VI, cl. 2.

${ }^{213}$ See, e.g., Damrosch, supra note 4, at 527; Henkin, supra note 4, at 346.

${ }^{214}$ Henkin, supra note 4 , at 346.

${ }^{215} I d$. at 348 . 
Three examples illustrate this point. First, the Supremacy Clause makes federal statutes, like treaties, the supreme law of the land. Nonetheless, Congress frequently specifies that federal statutes do not preempt state law, do not invalidate prior federal law, or do not create a private cause of action. ${ }^{216}$ Second, although congressional-executive agreements-which are equivalent to treaties on the international plane-are considered part of the supreme law of the land, ${ }^{217}$ it is widely accepted that Congress and the President can limit the selfexecuting effect of these agreements. ${ }^{218}$ Third, and most directly relevant, it has long been settled that, notwithstanding the Supremacy Clause, not all treaties are self-executing. ${ }^{219}$

With respect to the last point, critics of the RUDs generally concede that not all treaties are self-executing. They argue, however, that the self-execution issue must be resolved solely by reference to the terms of the treaty negotiated with foreign nations, not by conditions unilaterally imposed on the treaty by the Senate or President. Nothing in the language of the Supremacy Clause or in U.S. historical tradition suggests that this is true. As noted above, federal lawmakers generally have the power to limit the domestic effects of their enactments, and there is no reason to believe that the treatymakers should

${ }^{21 i t}$ For examples of statutes with these limitations, see 8 U.S.C. $\$ 1158$ (d) (7) (Supp. 1996) ("Nothing in this subsection [concerning asylum applications] shall be construed to create any substantive or procedural right or benefit that is legally enforceable by any party against the United States or its agencies or officers or any other person."); 16 U.S.C. \$ 5204 (1994) ("This chapter does not preempt a State law or local ordinance that provides for civil or criminal penalties for conduct that violates this chapter."); 18 U.S.C. $\$ 38(2000)$ ("This section does not preempt or displace any other remedy, civil or criminal, provided by Federal or State law for the fraudulent importation, sale, trade, installation, or introduction into commerce of an aircraft or space vehicle part.").

${ }^{217}$ RESTATEMENT (THIRD) OF THE FOREIGN RELATIONS LAW OF THE UNITED STATES $\$ 111$ (1987).

${ }^{214}$ See, e.g., HENKIN, supra note 24, at 217 n.*; Damrosch, supra note 4, at 525-26; Riesenfeld \& Abbott, supra note 4, at 641. For example, in the Uruguay Round Agreements Act, which authorizes the latest GATT agreement, Congress stated that: "No provision of any of the Uruguay Round Agreements, nor the application of any such provision to any person or circumstance, that is inconsistent with any law of the United States shall have effect." Pub. L. No. 103-465, $\S 102(a)(1), 108$ Stat. 4809 (1994). Congress also stated that no one other than the United States "shall have any cause of action or defense under any of the Uruguay Round Agreements" or challenge "any action or inaction ... of the United States, any State, or any political subdivision of a State on the ground that such action or inaction is inconsistent" with one of the agreements. Id. \$ $102(\mathrm{c})(1)$.

${ }^{214}$ Terlinden v. Ames, 184 U.S. 270,288 (1902); Foster v. Neilson, 27 U.S. (2 Pet.) 253, 314 (1829), overruled in part by United States v. Percheman, 32 U.S. (7 Pet.) 51 (1833). 
have less power in this regard. Moreover, it has long been accepted that, for separation of powers reasons, certain treaties, such as those that declare war, create criminal liability, appropriate money, or impose taxes, are non-self-executing regardless of their terms. ${ }^{220}$

In any event, even if it were true that the issue of self-execution had to be determined solely by reference to the terms of the treaty, the United States's non-self-execution declarations are in fact part of the terms of the treaties. They are included within the U.S. instrument of ratification that defines the nature of the U.S. obligations to other countries, and all other parties to the treaties are on notice of them. ${ }^{221}$ Moreover, unlike some of the United States's substantive reservations, no nation has specifically objected to the non-self-execution declarations. It would be difficult for any nation to do so since many nations' constitutions render all treaties non-self-executing and require separate implementing legislation for the treaties to have domestic force. Thus, even if the treatymakers could control the domestic scope of a treaty only by including limitations within the treaty itself, a point for which there is no support, that is precisely what the non-self-executing declarations accomplish.

Critics of the RUDs sometimes quote from early historical materials to the effect that the inclusion of treaties in the Supremacy Clause was designed to reduce treaty violations attributable to the United States. They argue that non-self-execution declarations may contravene this purpose by heightening the risk that the United States will violate international law. ${ }^{222}$ None of this historical evidence, however, suggests that the Supremacy Clause was meant to limit the treatymakers' control over the domestic force of treaties. Rather, it shows only that the Framers wished to give the national government the power to

${ }^{220}$ See, e.g., The Over the Top, 5 F.2d 838, 845 (D. Conn. 1925); RESTATEMENT (THIRD) OF THE FOREIGN RELATIONS LAW OF THE UNITED STATES $\$ 111$ reporters' note 6 (1987); CRS STUDY, supra note 15 , at $48-49$.

${ }^{221}$ This is a point that has consistently been emphasized by the Senate and various presidential administrations. See, e.g., 1979 Hearings, supra note 80, at 40 (statement of Jack Goldklang, Department of Justice); GENOCIDE CONVENTION REPORT, supra note 89, at 16-17. The fact that the RUDs are included within the U.S. instrument of ratifcation distinguishes them from, for example, the twenty-eight "conditions" adopted by the Senate in connection with its approval of the Chemical Weapons Convention, a treaty that expressly disallows reservations. Resolution of Ratification for the Chemical Weapons Convention, S. Res. 75, 105th Cong., 143 CoNG. REC. S3651 (daily ed. Apr. 24, 1997) (enacted).

${ }_{222}$ See, e.g., Halberstam, supra note 4, at 58; Carlos Manuel Vázquez, The Four Doctrines of Self-Executing Treaties, 89 AM.J. INT'L L. 695, 716-17 (1995). 
prevent treaty violations by U.S. states if they so desired. ${ }^{223}$ The inclusion of treaties in the Supremacy Clause, in other words, was designed to enhance the ability of the federal government to compel state compliance with treaties, not to restrict the federal government's flexibility in determining whether and how to comply with international law.

\section{Scope of the Treaty Power}

The second argument made against the non-self-execution declarations is that even if they do not violate the Supremacy Clause, they exceed the scope of the treaty power. Here it is argued that Article II only allows the treatymakers to make "Treaties," and that non-selfexecution declarations are not encompassed within that term. These declarations, the argument goes, concern only the domestic implementation of the treaty and thus are not part of the international agreement itself. ${ }^{224}$ As Professors Riesenfeld and Abbott put it, the Senate "does not have a constitutionally mandated power to unicamerally adopt rules applicable to the United States or its citizens merely because the Senate purports to act under the treaty power.",225

There are a number of problems with this argument. As noted above, the RUDs are approved by the Senate and President together and thus are not unicamerally imposed by the Senate. Moreover, the non-self-execution declarations are included within the U.S. instrument of ratification, and other nations are therefore on notice of the declarations and have an opportunity to object to them. As a result, they do in fact form part of the international agreement-the "Treaty," to use the term in Article II-entered into by the U.S. treatymakers.

To the extent that critics of the RUDs are arguing that the treaty-

For documentation of this point, see John C. Yoo, Globalism and the Constitution: Treaties, Non-Self-Execution, and the Original Understanding, 99 CoLUM. L. REV. 1955, 1955 (1999), and John C. Yoo, Treaties and Public Lawmaking: A Textual and Structural Defense of Non-Self-Execution, 99 Colum. L. REv. 2218, 2218 (1999). See also THE FEDERALIST No. 22, at 151 (Alexander Hamilton) (Clinton Rossiter ed., 1961) (noting that, under the Articles of Confederation, "[t]he treaties of the United States . . . are liable to the infractions of thirteen different legislatures"); 1 THE RECORDS OF THE FEDERAL CONVENTION OF 1787, at 316 (M. Farrand ed., 1911) (noting concern by James Madison regarding "[t]he tendency of the States to these violations" of the law of nations and treaties).

2:24 See, e.g., Dearborn, supra note 4, at 239-44; Halberstam, supra note 4, at 68-70; Quigley, supra note 4, at 1303-05; Riesenfeld \& Abbott, supra note 4, at 590-600.

Riesenfeld \&: Abbott, supra note 4, at 589 . 
makers lack the power under Article II to include treaty conditions that are "domestic" in nature, their argument proves too much. If the treaty power did not encompass "domestic" matters, human rights treaties, and not just their non-self-execution declarations, would be suspect. These treaties regulate the internal relationships between governments and their citizens. Moreover, as international tribunals have recognized, these treaties do not impose reciprocal obligations in any meaningful sense. ${ }^{226}$ For these reasons, a number of international law scholars, as well as the Restatement (Third) of the Foreign Relations Law of the United States, have denied that there is any "international" subject matter requirement for the treaty power. ${ }^{227}$

Critics of the RUDs have not disputed this general proposition; instead, they claim that the treatymakers in effect have the power to make treaties on any subject but no power whatsoever to determine the treaties' domestic effects. There is nothing in the Treaty Clause or constitutional practice under it that suggests such an unlikely distinction. The treaty power has a dual nature-it is a power to make international agreements, but it is also a power to make supreme federal law. Just as Congress's Article I powers to make legislation include the power to limit the effect of the legislation in U.S. courts, so too should the treatymakers' Article II powers to make treaties be construed to include the power of domestic limitation. ${ }^{228}$ Indeed, under the nonself-execution doctrine, it is already well established that the treatymakers can control domestic implementation by agreeing to treaty terms that are not in themselves self-executing. The non-selfexecution declarations are simply treaty terms that achieve this result more generally.

Support for this conclusion comes from the practice of congressional-executive agreements. As mentioned above, non-self-execution

${ }^{226}$ For example, as noted above, the International Court of Justice has stated that with human rights treaties, "one cannot speak of individual advantages or disadvantages to states, or of the maintenance of a perfect contractual balance between rights and duties." 1951 I.C.J. at 23; see supra note 144 and accompanying text. Similarly, the ICCPR's Human Rights Committee has stated that human rights treaties "are not a web of inter-State exchanges of mutual obligations" and that the "principle of inter-State reciprocity has no place" in this context. General Comment 24(52), supra note 121, 117.

${ }^{227}$ RESTATEMENT (THIRD) OF THE FOREIGN RELATIONS LAW OF THE UNITED STATES $\$ 302$ reporters' note 2 (1987); HENKIN, supra note 24, at 197-98.

${ }^{228} C f$. RESTATEMENT (THIRD) OF THE FOREIGN RELATIONS LAW OF THE UNITED STATES $\$ 303$ reporters' note 4 (1987) (explaining that the attachment of a non-selfexecution declaration by the Senate "is an expression of the Senate's constitutional authority to grant or with hold consent to a treaty"). 
declarations can be attached to congressional-executive agreements. ${ }^{229}$ This shows that nothing inherent in the power to make international agreements precludes control over the domestic scope of these agreements. In addition, the dramatic increase in the use of congressional-executive agreements in place of treaties has been justified on the ground that the bicameral process for making international agreements better reflects majoritarian preferences than does the twothirds senatorial consent process. ${ }^{230}$ But this is precisely the end served by non-self-execution declarations, which ensure that important domestic legal changes are implemented through the bicameral legislative process. The non-self-execution declarations are thus justified by the same majoritarian aims that support the interchangeability of congressional-executive agreements and treaties. ${ }^{231}$

\section{Potential Limits}

We do not mean to suggest that there are no limitations on the conditional consent power of the President and Senate. Presumably, the conditional consent power is subject, like the treaty power more generally, to the individual rights protections in the Bill of Rights. ${ }^{232}$ We can imagine three additional limitations. We do not necessarily embrace these limitations; we merely wish to show that these possible limitations would not apply to the conditions imposed in connection with human rights treaties.

One possible limitation is that the condition must have some relationship to the treaty. As the Restatement (Third) of the Foreign Relations Law of the United States argues, "[s] urely, a condition that has no relation to the treaty would be improper, for example, a requirement that the President dismiss or appoint some cabinet officer." 233 This limitation is simply a weak nexus requirement that presumably attaches to all exercises of constitutional power. ${ }^{234}$ As the Restatement (Third) ac-

24' Set supra note 218 and accompanying text.

HENKIn, supra note 24, at 217.

«.s1 Although we do not dispute the general constitutionality of congressionalexecutive agreements, we take no position here on the proper degree of interchangeability between such agreements and Article II treaties.

${ }^{212}$ Sec Boos v. Barry, 485 U.S. 312, 324 (1988); Reid v. Covert, 354 U.S. 1, 16 (1957) (plurality opinion).

235 RESTATEMENT (THIRD) OF THE FOREIGN RELATIONS LAW OF THE UNITED STATES $\$ 303 \mathrm{cmt} . \mathrm{d}$ (1987).

${ }^{2 / 44}$ For example, the Supreme Court has held that conditions attached by Congress in the exercise of its spending power must have a reasonable relationship to the purpose of the spending. South Dakota v. Dole, 483 U.S. 203, 207-08 (1987). 
knowledges, the non-self-execution declarations meet this requirement, since they concern the terms and domestic status of the treaty in question. ${ }^{235}$

A second possible limitation is that the Senate cannot use its conditional consent power to alter pre-existing federal law. This limitation is suggested by the D.G. Circuit's decision in Power Authority of New York v. Federal Power Commission. ${ }^{236}$ The question there was the validity of a Senate condition, labeled a "reservation," to a treaty between the United States and Canada concerning use of the waters of the Niagara River. ${ }^{237}$ The reservation stated that "no project for redevelopment of the United States' share of such waters shall be undertaken until it be specifically authorized by Act of Congress. ${ }^{228}$ The question in Power Authority was whether the reservation invalidated the Federal Power Commission's pre-existing licensing authority under the Federal Power Act of 1920. ${ }^{239}$ The D.C. Circuit concluded that the reservation did not have this effect because, despite its label, it was not intended by the Senate to be a condition of ratification. ${ }^{240}$

In reaching this conclusion, the court suggested that if the Senate had intended the statement to be a condition of ratification, the condition might have been beyond the Senate's powers. ${ }^{241}$ To the extent the court was insinuating that non-self-execution declarations per se are constitutionally suspect, we disagree for the reasons already outlined above. ${ }^{242}$ Our present concern is with a narrower limitation sug-

${ }^{235}$ RESTATEMENT (THIRD) OF THE FOREIGN RELATIONS LAW OF THE UNITED STATES $\S 303 \mathrm{cmt} . \mathrm{d}(1987)$.

${ }^{296} 247$ F.2d 538 (D.C. Cir. 1957), vacated and remanded with directions to dismiss as moot sub nom. Am. Pub. Power Assoc. v. Power Auth., 355 U.S. 64 (1957).

${ }^{237}$ Convention on Uses of the Waters of the Niagara River, Feb. 27, 1950, U.S.Can., 1 U.S.T. 694, T.I.A.S. No. 2130.

${ }^{238}$ Id. at 699 .

239 16 U.S.C. $\$ 791 \mathrm{la}-830$ (1994).

${ }^{240}$ One of the three judges on the panel dissented, arguing that the Senate intended its "reservation" to be a condition of ratification and that the condition was a valid exercise of the Senate's advice and consent power because it was related to the treaty. Power Auth., 247 F.2d at 544 (Bastian, J., dissenting). The dissenting judge also argued that if the condition were in fact beyond the Senate's powers, the United States would not be a party to the treaty at all because the Senate would not have given effective consent. $I d$.

${ }^{241} I d$. at 543.

${ }^{242}$ Some have drawn this inference from the court's statement that the Constitution might not allow the federal treatymakers to create binding treaties, or conditions on treaties, addressing matters of "purely domestic concern." Power Auth., 247 F.2d at 543; see Halberstam, supra note 4, at 69; Quigley, supra note 4, at 1303-05; Riesenfeld \& Abbott, supra note 4, at 590-600. For a strong defense of the Niagara reservation's validity, see Henkin, supra note 41; see also Damrosch, supra note 4, at 527 n.48 (conclud- 
gested by Power Authority. The Senate's "reservation" in that case, if treated as a binding treaty condition, would have limited the effect of a pre-existing domestic statute that, by its terms, governed the development of the Niagara River waters. The court might have believed that the Senate was attempting, through its conditional consent power, to change existing law without the involvement of the House of Representatives. ${ }^{243}$ Assuming that this characterization of the Niagara reservation is accurate, ${ }^{244}$ it is conceivable that such an exercise of the conditional consent power would exceed the Senate's powers under Article II. On the other hand, longstanding case law suggests that U.S. treatymakers acting together have the power to override a prior inconsistent federal statute, ${ }^{245}$ so it is not clear why the Senate cannot condition its consent on such an effect. In any event, such a limitation would not affect the validity of non-self-execution declarations, which are designed to avoid changing existing law without full participation of the House. ${ }^{246}$

Third, and finally, the Senate's conditional consent power might be limited to the extent that it unduly impinges on the prerogatives of

ing that the reasoning of the Power Authority decision "would probably not be extended to non-self-executing declarations"); cf. Power Auth., 247 F.2d at 542 (stating that "[t]he Senate could, of course, have attached to its consent a reservation to the effect that the rights and obligations of the signatory parties should not arise until the passage of an act of Congress" and that "[s] uch a reservation, if accepted by Canada, would have made the treaty executory").

:48 That is precisely how Professors Philip Jessup and Oliver Lissitzyn characterized the issue in a brief they submitted in support of the Power Authority. Opinion of Phillip C. Jessup \& Oliver J. Lissitzyn for the Power Authority of the State of New York (Dec. 1955), quoted in Bishop, supra note 138, at 319-20.

2*4 Professor Henkin contested that characterization of the Niagara reservation, arguing that "[t]he President and Senate have merely refused to throw new and valuable resources into an old established system of development which Congress may not have intended and may not now desire." Henkin, supra note 41, at 1173.

:25. See supra note 3. In truth, although U.S. case law refers to a last-in-time relationship between treaties and conflicting federal statutes, most decisions applying this rule have involved statutes that override treaties rather than treaties that override statutes.

"4ti Perhaps the best reading of Power Authority is that it simply applies an interpretive presumption against overriding federal legislation by means of treaty conditions. If so, it may be consistent with the general presumption against repealing federal statutes by implication. See, e.g., United States v. United Continental Tuna Corp., 425 U.S. 164, 168 (1976) (stating that "[i]t is a cardinal principle of statutory construction that repeals by implication are not favored"); Posadas v. Nat. City Bank, 296 U.S. 497, 503 (1936) (same). It is also consistent with what appears to be a trend in recent lower court decisions towards a presumption against interpreting treaties to be selfexecuting. Goldstar (Panama) S.A. v. United States, 967 F.2d 965, 968 (4th Cir. 1992); More v. Intelcom Support Servs., Inc., 960 F.2d 466 (5th Cir. 1992); Frolova v. U.S.S.R., 761 F.2d 370, 374 (7th Cir. 1985). See generally Bradley, supra note 185, at 541 (discussing this trend). 
the other branches of the federal government. By analogy, Article II gives the Senate a role in consenting to the appointment of ambassadors, judges, and other officers in addition to its role in consenting to treaties. It is possible that conditions attached by the Senate to such appointments-such as a condition requiring that an appointed judge vote a certain way, or a condition requiring that an ambassador pursue a particular policy with another country-would be unconstitutional. If so, it would be because the condition interfered with the constitutional prerogatives of another branch, such as the independence of the judiciary or the executive's discretion in conducting foreign affairs. The RUDs to the human rights treaties do not raise such constitutional concerns. As we explained above, they do not impinge on the power of the judiciary because they merely determine the content of the law to be interpreted, a power that federal lawmakers uncontroversially possess. ${ }^{247}$ Similarly, since the conditions concern only the scope and content of treaties-the ratification of which are the joint responsibility of the Senate and President-they do not interfere with whatever sole discretion the executive has over foreign affairs. ${ }^{2+8}$

\section{E. Federalism}

As noted, the package of RUDs typically includes a federalism understanding that emphasizes that treaties do not affect the constitutional balance of authority between the state and federal governments. Many commentators believe that there are no federalism limitations on the treaty power, and therefore they question the need for these understandings. ${ }^{249}$ For reasons we have articulated elsewhere, we disagree with this view. ${ }^{250}$ The important issue for now is

${ }^{247}$ See supra text accompanying notes 216-19.

248 See supra text accompanying notes 204-07.

249 See Henkin, supra note 4, at 345; Weissbrodt, supra note 4, at 66; see also Damrosch, supra note 4 , at 530-31 (arguing that non-self-execution declarations are not needed to protect federalism).

${ }^{250}$ As one of us has explained elsewhere, commentators who view the federalism understandings as unnecessary may be reading Missouri v. Holland, 252 U.S. 416 (1920), more expansively than is warranted. Curtis A. Bradley, The Treaty Power and American Federalism, 97 MICH. L. REV. 390, 425-26 (1998). Although the Court in Holland suggested that the treaty power was broader than Congress's Article I powers, it did not hold that the treaty power was immune from all federalism limitations. See 252 U.S. at 433-34 ("We do not mean to imply that there are no qualifications as to the treaty-making power; but they must be ascertained in a different way .... We must consider what this country has become in deciding what [the Tenth] Amendment has reserved."). In any event, Holland was decided before both the development of modern human rights treaties and the tremendous expansion of Congress's domestic legis- 
not necessity, but rather the legality of the federalism understandings.

The most common legal argument made against the federalism understandings is that they are inconsistent with the general liability of federal nations under international law for the actions of their constituent states. This principle is reflected in Article 50 of the ICCPR, which states that " $[t]$ he provisions of the present Covenant shall extend to all parts of federal States without any limitations or exceptions." ${ }^{\text {,251 }}$ This argument is obviously not a domestic constitutional argument. In any event, the argument is beside the point because the federalism understandings do not purport to deny the liability of the United States for the actions of its states. Rather, the federalism understandings simply note that, because of the federal nature of the U.S. government, some of the treaty obligations may be implemented at the state level rather than the federal level. As the Bush Administration explained when it submitted a federalism understanding to the Senate in connection with the ICCPR, "the intent is not to modify or limit U.S. undertakings under the Covenant but rather to put our future treaty partners on notice with regard to the implications of our federal system concerning implementation."

In a recent article, Professor Carlos Vázquez attempted to use constitutional federalism concerns against the federalism understandings. As he notes, in recent years the Supreme Court has held that the Tenth Amendment bars the federal government from "commandeering" state governments. ${ }^{253}$ Vázquez argues that if this anticommandeering restriction applies to the treaty power, it might be violated by the federalism understandings. ${ }^{254}$ He observes that the United States has an international law duty to implement its treaty obligations. "Thus," he says, "the federalism understanding, alongside the non-selfexecuting declaration, appears to commandeer state legislatures to

lative powers-developments that might alter the need for, and desirability of, the Holland approach to the treaty power. This conclusion finds support in the Supreme Court's renewed emphasis on federalism limits on the national government, even in the foreign affairs context. See generally Curtis A. Bradley \& Jack L. Goldsmith, The Abiding Relevance of Federalism to U.S. Foreign Relations, 92 AM. J. INT'L L. 675 (1998).

ICCPR, supra note 10, art. 50, 999 U.N.T.S. at 185.

252 ICCPR REPORT, supra note 95, at 18.

${ }^{253}$ Printz v. United States, 521 U.S. 898, 933 (1997); New York v. United States, 505 U.S. 144, 149 (1992).

${ }^{254}$ Carlos Manuel Vâzquez, Breard, Printz, and the Treaty Power, 70 U. Colo. L. REV. 1317, 135457 (1999); of. Gerald L. Neuman, The Global Dimension of RFRA, 14 CONST. COMMENTARY 33, 52 (1997) (noting possible tension between the anticommandeering principle and the federalism understandings in the RUDs). 
pass the laws the treaty requires." 255

The obvious response to Vázquez is that the federalism understandings are not intended to compel state action. These understandings, in other words, are not designed to carry out an international law duty but rather to make a political statement about the federal nature of the U.S. system. Vázquez recognizes this possibility, but he replies that "if the purpose of this understanding is to make compliance with these treaties ultimately a matter of the states' option, then the resulting regime is in deep tension with our constitutional scheme. ${ }^{256}$ It is in deep tension with our constitutional scheme, he says, because it allows for the possibility that some state violations of treaties will not be prevented by the federal government. ${ }^{257}$ Vázquez thus ultimately returns to the argument, discussed above, that the Supremacy Clause is designed to reduce treaty violations. The historical evidence, however, does not show that it was designed to reduce treaty violations allowed by the federal government. ${ }^{258}$ By analogy, the dormant Commerce Clause is designed to reduce state interference with interstate commerce, but it does not preclude the federal government from authorizing such interference. ${ }^{259}$

In any event, Vázquez is wrong to assume that it is the understandings that might make treaty compliance "a matter of the states' option"- the understandings merely highlight the possibility that the federal structure of the Constitution may have this effect. If, as some commentators argue, there are no federalism limitations on the national government's ability to implement treaties, then the federalism understandings are inconsequential. On the other hand, if there are federalism limitations on the treaty power, then these understandings are useful signals to U.S. treaty partners. In neither scenario are they unconstitutional.

\section{POLICY IMPLICATIONS OF CONDITIONAL CONSENT}

We have tried to show why U.S. RUDs practice is consistent with both international law and U.S. constitutional law. Critics of the RUDs, however, do not rely solely on legal arguments. Closely tied to

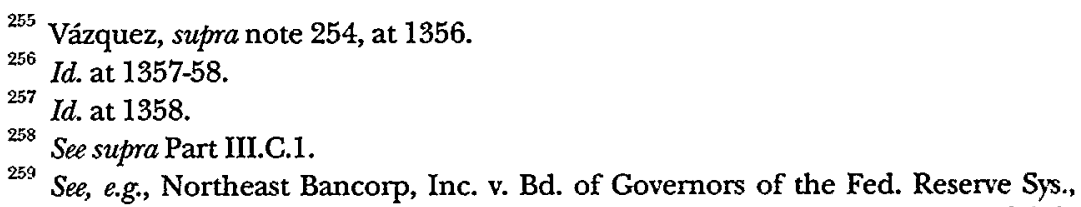
472 U.S. 159, 174 (1985) ("When Congress so chooses, state actions which it plainly authorizes are invulnerable to constitutional attack under the Commerce Clause."). 
their legal objections is the view that the RUDs practice is, regardless of its legality, bad policy. The policy criticisms are of two general types. The first concerns the message that RUDs send to the international community. The message, it is claimed, is that the United States does not take international human rights law seriously. ${ }^{260}$ The second criticism concerns the effect this message has on the international community. This effect is supposedly to undermine international human rights protection. ${ }^{261}$

As we explain below, these criticisms are misplaced on several levels. Perhaps most importantly, they fail to take account of the many virtues of the RUDs practice. They also rest on a perfectionist view of international human rights law, as well as an idealized view of domestic and international politics. And, ironically, they might well do more harm than good with respect to U.S. participation in international human rights law regimes and, because of the importance of U.S. participation, to the broader human rights movement itself.

\section{A. Virtues of the RUDs}

Human rights treaties-especially treaties like the ICCPR-have a dual nature. They are in part law-a single legal text designed to establish international obligations among all of the countries of the world. And they are in part aspiration-broad, universalistic norms designed to change national and individual attitudes toward human rights in the face of substantial variations in culture, political systems, moral commitments, and the like. Given this dual nature, as well as the heterogeneity of the world community, it is virtually impossible to reach agreement on a treaty text that is acceptable to all nations. This is why, as was recognized in the early days of the human rights movement, conditional consent is so important. The practice mediates the legal and aspirational natures of human rights treaties. It recognizes

2int See, e.g., Henkin, supra note 4, at 341 ("As a result of those qualifications of its adherence, U.S. ratification [of the human rights treaties] has been described as specious, meretricious, hypocritical."); Paust, supra note 4, at 1257 ("Rarely has a formal attempt at adherence to a treaty been so blatantly meaningless and so openly defiant of its terms, the needed efficacy of its norms, and the very possibility of its direct application as supreme law of the land.").

viil See, e.g., Henkin, supra note 4, at 349 ("U.S. ratification practice threatens to undermine a half-century of effort to establish international human rights standards as international law."); Weissbrodt, supra note 4, at 78 ("By offering such an extensive and intensive set of reservations to the Covenants ... those who drafted these proposals may have undermined the basic purpose of ratifying these treaties: encouraging the implementation of human rights throughout the world."). 
that nations of the world are politically and culturally diverse, and makes it possible to reach agreement on and movement toward general principles of human rights while at the same time accommodating national differences. ${ }^{262}$

This mediating function has been particularly crucial for U.S. participation in the international human rights movement. Since the founding of the nation, many segments of American society have ferociously resisted international entanglements. Sometimes this resistance has been grounded in crass xenophobia. Often, however, it has rested on more defensible grounds. One such ground is a fundamental belief in self-government. This belief underlies both a preference for local decisionmaking and a general concern about the nondemocratic and nontransparent ways in which much international law is made. In addition, many Americans are understandably proud of the human rights protections guaranteed by the Bill of Rights and the Reconstruction Amendments, as well as the vigorous domestic judicial system that enforces them. They worry that U.S. involvement in international human rights regimes might threaten these domestic rights protections, in addition to the liberties guaranteed by the separation of powers and federalism. A final ground for resisting international entanglements is the belief that Americans can improve the lot of humanity abroad not by active engagement in international and foreign affairs, but rather by the excellence of its "example [as] a humane, democratic, and prosperous society. ${ }^{263}$

Whatever its source and motivation, U.S. resistance to international entanglements has been an especially potent force in the twentieth century, resulting in, among other things, the United States's rejection of the Versailles treaty, the Bricker Amendment debates, and

${ }^{262}$ In this respect, conditional consent is akin to the European Court of Human Rights's "margin of appreciation" doctrine, which gives deference to national differences when enforcing the universalistic norms of the European Convention on $\mathrm{Hu}$ man Rights. The doctrine recognizes that in and among pluralistic democratic societies, there is reasonable scope for disagreement over the requirements of broadly worded human rights provisions. The doctrine thus aims to reconcile the tension between national democratic decisionmaking and universal aspirational norms. It also aims to avoid damaging confrontations with national authorities, and thereby gradually to legitimize international human rights norms. See generally HOWARD CHARLES Yourow, THE MARGIN OF APPRECIATION DOCTRINE IN THE DYNAMICS OF EUROPEAN HUMAN RIGHTS JURISPRUDENCE (1996).

${ }^{263}$ H.W. BRANDS, WHAT AMERICA OWES THE WORLD: THE STRUGGLE FOR THE SOUL OF FOREIGN POLICY, at vii (1998). This "exemplarist" approach to international human rights traces its lineage to George Washington and John Quincy Adams. Id. at 2-9. 
the forty-year refusal to ratify modern human rights treaties. ${ }^{264}$ Against this background, the RUDs are an extraordinarily important development. They helped break the logjam in domestic politics that had prevented U.S. ratification of any of the major human rights treaties. $^{3 i j}$ And, contrary to conventionai wisdom in the human rights community, they did not do so in a way that rendered human rights commitments empty promises. Even with the RUDs, the United States has bound itself to almost all of the obligations in each of the four major human rights treaties it has ratified. It has enacted domestic criminal, civil, and immigration laws to implement the Genocide and Torture Conventions. ${ }^{266}$ Although the United States maintained that its pre-treaty domestic laws satisfied its obligations under the ICCPR and the Race Convention, it legally committed itself not to retreat from those laws. Finally, pursuant to the treaties, the United States has opened its domestic human rights practices to official international scrutiny by filing with international bodies a number of reports that describe and defend U.S. human rights practices.

In these and other ways, the United States has made genuine and significant progress towards involvement in the international human rights system. It is very unlikely that these steps would have been taken without the RUDs as a condition for U.S. ratification. The United States's evolution towards participation in international human rights regimes has been accompanied by a consensus among U.S. policymakers concerning the wisdom of the RUDs approach. RUDs have had the support of every President and the large majority of every Senate since the United States began considering the modern human rights treaties in the 1970s. This bipartisan and interbranch agreement is extraordinary when considered against the backdrop of the United States's post-1950s antagonism towards international human rights law. RUDs made this possible.

With these points in mind, we now consider the specific policy objections made against the RUDs.

\section{B. Message of the RUDs}

One prominent criticism of the RUDs is that they send a message of disrespect for international law in general, and international hu-

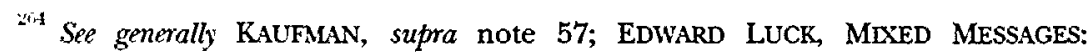
AMERICAN POLITICS AND INTERNATIONAL ORGANIZATION, 1919-1999, at 15-41 (1999).

See supra Part II.B.

See supra note 129 and accompanying text. 
man rights law in particular. ${ }^{267}$ As we have just reiterated, U.S. human rights commitments under the treaties, even with the RUDs, are far from empty promises. It is equally incorrect to say that the RUDs show disrespect for international law.

Consider first the U.S. reservations, which decline to consent to treaty provisions that violate the U.S. Constitution or that are inconsistent with widely supported criminal justice practices. The decision by the United States not to embrace these relatively few provisions does not constitute disrespect for international law. Many nations, including the most progressive nations in Western Europe, have also conditioned their consent to the treaties. ${ }^{268}$ While some nations have consented to the human rights treaties without condition, there does not appear to be any correlation between these nations, which include Libya and Iraq, and respect for international human rights law. As Arthur Rovine, a former Assistant Legal Adviser to the State Department and current President of the American Society of International Law, has noted, "It is very easy to sign a human rights treaty without any reservations ... . Many authoritarian regimes have done so." ${ }^{269}$

The central problem for international human rights law has not been selective consent to treaty terms, but rather the failure by nations to adhere to the treaty terms to which they have consented. The U.S. RUDs are expressly designed to ensure that the United States does not consent to an international obligation that it is unable, for constitutional or political reasons, to obey. One can object that the United States has not assumed all of the obligations under the human rights treaties, but it is wrong to conclude that the U.S. practice of declining consent to a small number of human rights obligations shows disrespect for international law. To the contrary, it is much more plausible to conclude that the care with which the United States crafts its consent shows respect for international law and an intention to comply with such law. ${ }^{270}$

${ }^{267}$ See Henkin, supra note 4, at 344; see also Schabas, supra note 4, at $283-84$. The legal aspects of this criticism are considered above, supra Part III.

268 See supra Part II.B.

${ }^{269}$ Arthur Rovine, Defense of Declarations, Reservations, and Understandings, in U.S. RATIFICATION OF THE HUMAN RIGHTS TREATIES: WITH OR WITHOUT RESERVATIONS? 57 (Richard B. Lillich ed., 1981).

${ }^{270}$ As Senator Moynihan explained in urging ratification of the ICCPR, the United States "has undertaken a meticulous examination of U.S. practice to insure that the United States will in fact comply with the obligations that it is assuming," which "can certainly be viewed as an indication of the seriousness with which the obligations are regarded rather than as an expression of disdain for the obligations." 138 CONG. REC. S4783 (daily ed. Apr. 2, 1992). Senator Moynihan is no opponent of international law. 
We make these points without purporting to defend the U.S. reservations, and the practices they immunize from international obligation, on their moral merits. We do not contend that the reservations can all be easily defended from this perspective, and, in any event, such a defense would require a different article. What is important for present purposes, however, is not our or anyone else's views about the moral desirability of domestic laws enacted in a free and democratic process, such as laws providing for capital punishment. Whatever the moral desirability of the death penalty, the United States shows no disrespect for international law in not abolishing it, for it has steadfastly declined to consent to any such international law, either in a treaty or by custom. The United States has, it is true, largely ignored international disapprobation of the juvenile death penalty (and the death penalty more generally), and it is certainly appropriate for nations (not to mention U.S. citizens) that disagree with this practice to criticize the United States. Nothing in our analysis takes issue with this. We insist only that being out of step with the rest of the world is not, in itself, a reason for a nation to change its domestic practices, and it certainly does not constitute disrespect for international law.

It is also incorrect to contend that the U.S. declaration of non-selfexecution shows disrespect for international law. Many nations require implementing legislation before a treaty has domestic effect, and there is no general obligation that a nation implement a treaty in any particular way. Moreover, the United States is under no obligation to change its domestic law after ratifying a human rights treaty if its law already satisfies the treaty obligations. Under the terms of the ICCPR, for example, nations are required to take steps to protect the rights under the treaty only if the rights are "not already provided for by existing legislative or other measures."271 The non-self-execution declarations therefore can be justified by the fact that the United States already provides sufficient domestic legal protections to fulfill its international obligations.

This latter proposition-that U.S. domestic law satisfies U.S. international human rights obligations-is open to debate. The reason it is open to debate, however, only strengthens the case for the nonself-execution declaration. It is open to debate because many human rights treaty terms are couched in broad, open-ended language. The resulting vagueness, combined with the absence of an authoritative 
treaty interpreter, makes it difficult in many contexts to determine whether U.S. domestic law satisfies its international obligations.

Consider just a few of literally hundreds of possible examples from the ICCPR. Can one say for sure that the absence of proportional representation in the United States is consistent with the ICCPR's "right of self-determination"? $?^{272}$ Is the Supreme Court's rejection of Lochner-style economic rights consistent with the ICCPR's guarantee of the right "freely [to] pursue their economic ... development"? ? $^{273}$ Are U.S. campaign finance laws consistent with the international human right to "have access, on general terms of equality, to public service" ${ }^{274}$ Is the United States's failure to prohibit some discrimination based on sexual orientation consistent with its obligation to "prohibit any discrimination and guarantee to all persons equal and effective protection against discrimination on any ground such as . . status"?

These questions, which can proliferate almost endlessly, show how difficult it is to tell with certainty whether the United States is complying with all the terms of a human rights treaty. This point sheds light on the persistent complaints that the United States is in widespread violation of the ICCPR. One can indeed interpret the ICCPR's terms to call into question scores of domestic laws in the United States and many other western democracies. But one can also easily read the ICCPR obligations as satisfied by current U.S. domestic law. There is no authoritative international body to resolve this "legal" disagreement; the ICGPR contemplates only that nations will open their human rights practices for other nations to see and, if they like, to criticize. The United States is a liberal democracy with extraordinary, although not perfect, statutory and constitutional human rights protections, and a federal judiciary that has historically protected individual rights. Its human rights protections come close enough to the line

${ }^{272}$ Id. art. 1(1), 999 U.N.T.S. at 173.

273 Id.

${ }^{274}$ Id. art. 25 (c), 999 U.N.T.S. at 179.

${ }^{275}$ Id. art. 26, 999 U.N.T.S. at 179 (emphasis added). The United Nations Human Rights Committee has, in fact, interpreted the ICCPR's antidiscrimination provision to cover discrimination on the basis of sexual orientation. Toonen v. Australia, U.N. GAOR Hum. Rts. Comm., 49th Sess., Supp. No. 40, vol. II, at 226, 233, U.N. Doc. $\mathrm{A} / 49 / 40$ (1994). Other human rights treaties raise similar interpretive questions. For example, does the use by U.S. law enforcement officials of stun belts to restrain prisoners violate the prohibition in the Torture Convention on "cruel, inhuman or degrading treatment or punishment"? See Torture Convention, supra note 85, 23 I.L.M. at 1027. The monitoring committee established by the Torture Convention recently said yes. Elizabeth Olson, U.S. Prisoner Restraints Amount to Torture, Geneva Panel Says, N.Y. TIMES, May 18, 2000, at A12. 
to conclude, with justification, that it need not incur the extraordinary costs of litigation and uncertainty that accompany direct incorporation of these treaty terms into its domestic litigation system.

Of course, some nations have chosen to incur such costs. The United Kingdom, for example, is in the process of incorporating the European Convention on Human Rights into its domestic law, notwithstanding the many legal uncertainties that this entails. ${ }^{276}$ It is worth noting, however, that the U.S. legal system differs from the U.K. system in a number of important respects. The United States has a 210-year-old written constitution, including a Bill of Rights; the United Kingdom has no written constitution, and it has been severely criticized for its lack of fundamental human rights protections. ${ }^{277}$ The United States has a long tradition of judicial review of national legislation; the United Kingdom does not. And the United States has a deeply entrenched federal structure; the United Kingdom, even with its recent "devolution" of power to Scotland and Wales, has nothing comparable. In addition to these legal differences, the size, location, and resources of the United States are such that it may not derive the same benefits as the United Kingdom (and other European nations) from coordinated legal regimes.

The U.S. preference for congressional, rather than judicial, monitoring of the extent to which domestic law comports with international obligations has an additional justification. Sometimes courts look to international bodies and the writings of scholars in giving content to international obligations. ${ }^{278}$ The ICCPR Human Rights Committee has no official interpretive authority over the ICCPR, but as its recent comments on treaty reservations indicate, the Committee is not a body that views itself as bound by consensus international law principles. ${ }^{274}$ Unfortunately, this desire to achieve progressive ends at the expense of broadly recognized international law principles also characterizes many academic writings about international human rights law. ${ }^{2(x)}$ Since these sources sometimes influence courts, it is understandable why the treatymakers want to maintain political, as opposed to judicial, control over the means of implementing the ICCPR's

${ }^{276}$ Human Rights Act, 1998, c. 42 (Eng.); see also Sarah Lyall, 209 Years Later, the English Get American-Style Bill of Rights, N.Y. TIMES, Oct. 2, 2000, at A3.

"277 Se, e.g., RONALD DWORKIN, A BILL OF RIGHTS FOR BRITAIN: WHY BRITISH LIBERTY NEEDS PROTECTING 1-9 (1990).

${ }^{27 s}$ See, e.g., Filartiga v. Pena-Irala, 630 F.2d 876 (2d Cir. 1980) (relying on, among other things, nonbinding United Nations declarations and views of scholars).

274 See supra text accompanying notes 133-37.

¿xai See Simma \& Alston, supra note 119. 
open-ended obligations.

We should emphasize that we are not suggesting that domestic law perfectly protects human rights, either as written or, especially, as enforced. In the United States, however, international law is not the principal solution to these problems. Rather, the principal solution is to work within U.S. democratic and constitutional processes to effectuate change and improvement. The critics of RUDs are obsessed with international solutions to human rights problems. This obsession elevates form over substance. Sometimes internationalization of human rights norms-defined as the delegation of human rights responsibilities to a supranational body-can help achieve domestic human rights reform. This was so in Europe, where there was a post-World War II desire for human rights improvement but an absence of confidence in domestic institutions to achieve those ends. ${ }^{281}$ What works for Europe, of course, will not necessarily work for the United States, which has a significantly different political culture (especially in its attitude towards international entanglements) and domestic human rights tradition. It was extraordinary for the United States to assent to the general norms in the ICCPR and to open its human rights practices to official international scrutiny. It does not follow, however, that human rights progress in the United States is best achieved by delegating the responsibility for determining the appropriate content of human rights to bodies outside the United States.

\section{Effect of RUDs}

We now move from the meaning of RUDs to their effect on the international human rights movement. We have seen no empirical evidence to support the claim that RUDs undermine or threaten international human rights law or the international human rights movement. Rather, there is much evidence to the contrary. The United States began ratifying modern human rights treaties fifteen years ago, and it has attached RUDs to all of the treaties. During this same period, international human rights law has, by any measure, flourished. ${ }^{282}$ It is,

${ }^{281}$ See Andrew Moravcsik, The Origins of Human Rights Regimes: Democratic Delegation in Postwar Europe, 54 INT'L ORG. 217 (2000).

${ }^{282}$ For example, over 140 nations are now parties to the ICCPR, and over 50 of these nations became parties in the 1990s. On the specific issue of the death penalty, numerous countries decided to restrict or abolish capital punishment during the 1990s, notwithstanding the United States's refusal to do so. Amnesty Int'l, The Death Penalty: List of Abolitionist and Retentionist Countries (Jan. 1, 2000), http:// www.amnesty.org/ailib/aipub/2000/ACT/A5000500.htm. 
of course, possible that the human rights movement would have flourished even more in the absence of U.S. RUDs. Beyond vague and conclusory platitudes, however, the critics of RUDs have not explained how or why this is so. ${ }^{283}$

The claim that the U.S. RUDs practice harms the human rights movement becomes even less convincing when one considers the many ways that the United States influences human rights development around the world outside the context of the human rights treaties. The United States exerts much of its influence through the example of its own, non-treaty-based human rights standards, which RUDs have not diminished at all. The United States is also the nation that most aggressively pressures other nations to improve their human rights standards-a practice once again not affected, at least directly, by the RUDs. More broadly, perhaps the greatest advance for international human rights was the defeat of the Soviet Union in the Cold War. The U.S. RUDs did not delay this victory. Indeed, one of the initial purposes of the RUDs was to increase U.S. participation in the international human rights community in order to rebut Cold War propaganda about U.S. human rights practices. ${ }^{284}$

These points indicate another error in the claim that the U.S. RUDs harm international human rights law. These criticisms assume an inappropriate baseline of comparison. They assume that compared to U.S. ratification without RUDs, RUDs harm international human rights. This is an inappropriate baseline of comparison because the RUDs were clearly a pre-condition to any U.S. ratification. ${ }^{285}$ The appropriate question is whether U.S. ratification with RUDs or no U.S. ratification at all is better for the international human rights movement. $^{2 \times 6}$ Viewed this way, it is hard to say that the RUDs, which facilitate U.S. engagement in the international human rights movement, harm the movement.

A related argument is that RUDs undermine the United States's

${ }^{243}$ When President Carter first proposed the RUDs package in the late 1970s, commentators expressed concern that the RUDs practice would induce other nations to opt out of many of the important treaty provisions. See, e.g., Weissbrodt, supra note 4 , at 56. In fact, the U.S. RUDs practice has not led to any substantial increase in the number or breadth of reservations by other countries. For documentation of this point, see the record of ratifications for the treaties set forth in United Nations Treaty Collection, at http://untreaty.un.org.

${ }^{2 \times 4} 1979$ Hearings, supra note 80 , at 21.

See supra Part I.B and text accompanying note 173.

2*ri See Jack Goldsmith, International Human Rights Law and the United States Double Standard, 1 GREEN BAG 2D 365, 373 (1998). 
ability to influence other nations' human rights practices. RUDs weaken U.S. credibility on human rights issues, the argument goes, thereby diminishing the effect of the nation's moral pressure. ${ }^{287}$ Again, critics have presented no empirical evidence to support this proposition. Evidence to the contrary includes the facts that most nations have not objected to the RUDs and that no nation has refused to enter into a treaty relationship with the United States as a result of its RUDs. In addition, when nations criticize U.S. credibility on human rights, usually in response to human rights criticisms from the United States, they do not generally refer to the RUDs. Rather, they attack substantive practices such as discrimination, police abuse, and the like, without mentioning the RUDs practice. ${ }^{288}$ This focus suggests that U.S. RUDs are not the currency of moral complaint, at least not in political debates between nations, as opposed to complaints from human rights activists. ${ }^{289}$

We cannot, and do not, claim that the U.S. RUDs practice has no effect whatsoever on international affairs. If nothing else, RUDs probably feed the suspicion in some circles that the United States is an arrogant superpower that disdains international law. We have tried to show that the premise of this complaint-that the U.S. RUDs practice shows disrespect for international law-is much less warranted than conventional wisdom suggests. Perceptions do, however, matter in international relations and this perception, warranted or not, might influence the international human rights movement. Critics of RUDs have so far not demonstrated the alleged causes or effects of this influence; nor have they shown that any realistic alternative to the U.S. RUDs practice would be better for the human rights movement.

It may also be true that RUDs reduce the opportunities for U.S. courts to interpret international human rights law and thereby con-

${ }^{287}$ See, e.g., Bassiouni, supra note 4, at 1173 ("The Senate's practice of de facto rewriting treaties, through reservations, declarations, understandings, and provisos, leaves the international credibility of the United States shaken and its reliability as a treaty-negotiating partner with foreign countries in doubt."); Damrosch, supra note 4, at 515-16 ("Regrettably, the non-self-executing declaration and others of its ilk could undermine the efficacy of the treaties to which they apply, both within the United States and in terms of the potential for the United States to exercise constructive influence abroad.").

${ }^{288}$ See, e.g., Eduardo Lachica, China Criticizes American Rights Report: Beijïng Responds to U.S. Critique With a list of Stinging Accusations, ASIAN WALL ST. J., Feb. 28, 2000, at 3, available at 2000 WL-WSJA 2935375; Russia Critical of U.S. Report on Human Rights, Dow JONES INT'L NEWS, March 1, 2000, available at WESTLAW, All News Plus Library, DJINS File.

${ }^{289}$ See Goldsmith, supra note 286 , at 372. 
tribute to the development of such law, as some commentators have complained. . $^{2(4)}$ This is a surprising criticism given that human rights advocates frequently complain that U.S. courts interpret international law too narrowly. ${ }^{291}$ In any event, numerous opportunities exist for U.S. officials to interpret international human rights law outside the context of judicial proceedings-for example, in their reports to the human rights committees-and these opportunities are unaffected by the RUDs. ${ }^{292}$

\section{CONCLUSION}

The rise of human rights treaties has placed great demands on the U.S. treatymaking process. U.S. treatymakers face international pressures to ratify human rights treaties and participate in international human rights regimes. Treatymakers also face significant domestic opposition to these treaties. Such opposition is grounded in a variety of factors ranging from concerns about altering domestic constitutional lawmaking processes, to general satisfaction with the domestic human rights law regime, to fear of international entanglement.

RUDs are a reasonable and largely successful response to these competing pressures. They have allowed the United States to make genuine international human rights commitments and to participate fully in debates about, and development of, international human rights law. RUDs also have opened up U.S. human rights practices to official international scrutiny. These are extraordinary advances for a nation that has instinctively, and sometimes vehemently, resisted the relinquishment of its sovereignty to international law and institutions.

At the same time, RUDs protect a range of domestic prerogatives.

${ }^{2 *+1)}$ See Weissbrodt, supra note 4 , at 67 (arguing that the non-self-execution declarations "deprive American courts of their most potent technique for contributing meaningfully to the interpretation of the Human Rights Covenants").

*al Recent Supreme Court decisions that have been heavily criticized by human rights advocates for their interpretation of international law include Breard v. Greene, 523 U.S. 371 (1998), Sale v. Haitian Centers Council, Inc., 509 U.S. 155 (1993), and United States v. Alvarez-Machain, 504 U.S. 655 (1992).

${ }^{242}$ Furthermore, U.S. courts have long applied a canon of construction pursuant to which federal statutes are construed, where reasonably possible, so that the statutes do not violate international law. See Murray v. The Schooner Charming Betsy, 6 U.S. (2 Cranch) 64, 117-18 (1804); Curtis A. Bradley, The Charming Betsy Canon and Separation of Powers: Rethinking the Interpretive Role of International Law, 86 GEO. L.J. 479, 483 (1998). In applying this canon, courts will have opportunities to construe the human rights treaties. See, e.g., Ma v. Reno, 208 F.3d 815 (9th Cir.), cert. granted, 1221 S. Ct. 297 (2000); Maria v. McElroy, 68 F. Supp. 2d 206 (E.D.N.Y. 1999); Mojica v. Reno, 970 F. Supp. 130 (E.D.N.Y. 1997). 
They ensure that the United States does not make international legal commitments that it cannot fulfill for domestic constitutional or political reasons. RUDs leave the concrete implementation of vague human rights commitments to the federal political branches rather than the courts. They also help preserve Congress's traditional role in enacting domestic human rights protections, as well as the states' traditional role in regulating local matters. As we hope to have shown, RUDs achieve these ends in a manner that is consistent with both international law and U.S. constitutional law.

In light of these points, it might seem surprising that the legal academy and the international human rights community have been so strongly opposed to the RUDs. Their opposition to RUDs, however, is simply one example of the idealistic and perfectionist orientation of these groups-an orientation that tends to overvalue the role of international institutions and undervalue domestic political and structural concerns. Although idealism obviously plays a crucial role in human rights advocacy, the exaggeration and impatience that characterize the opposition to RUDs threaten to make U.S. officials less inclined, not more inclined, to continue their involvement with international institutions. ${ }^{293}$ In this respect, as with so many other international human rights issues, the perfect becomes the enemy of the good, and aspiration becomes the enemy of the law.

${ }^{293}$ To take one of many examples, the ICCPR Human Rights Committee's General Comment 24(52) concluded that some U.S. reservations to the ICCPR were invalid. See supra notes 135-36 and accompanying text. In response, Congress passed a bill, later vetoed by the President, that would have cut off funding for U.S. obligations under the Covenant unless the Committee "expressly recognized the validity [of U.S. RUDs] as a matter of international law." Foreign Relations Authorization Act, Fiscal Years 1996 and 1997, H.R. 1561, 104th Cong. $\$ 1504$ (2d Sess. 1996). 